\title{
TOXICITY, NATURAL AND INDUCED DEGRADATION OF CHLORPYRIFOS
}

\author{
DHIRAJ SUD ${ }^{a}$, JITESH KUMAR $^{b}$, PARAMJEET KAUR ${ }^{c}$ AND PRITI BANSAL ${ }^{b *}$ \\ ${ }^{a}$ Department of Chemistry, Sant Longowal Institute of Engineering and Technology, Longowal 148106, India. \\ ${ }^{b}$ Department YCoE, T. Sabo, Punjabi University, Patiala 147002, India. \\ ${ }^{c}$ Department of Chemistry, DAV College, Bathinda 151001, India.
}

\begin{abstract}
The increase in demand for agricultural products due to the growing population led to excessive inputs of pesticides in the agriculture field which resulted in contamination of the environmental segments of life i.e. air, water, and soil. Chlorpyrifos is one of the most extensively used broad-spectrum organophosphate insecticides. The usage and broad-spectrum applicability of chlorpyrifos lead to widespread contamination in the environment and serious damage to non-target organisms. Moreover, metabolites of chlorpyrifos i.e. chlorpyrifos-oxon and 3,5,6-trichloro-2-pyridinol are found to be more toxic than its parent compound. This review emphasizes on various toxic effects of chlorpyrifos and its metabolites on living organisms. The efforts put to develop the efficient methods for the degradation of the insecticide in soil and water i.e. photocatalytic, biodegradation, electrochemical and others have been discussed. Analytical techniques used for the study of degraded products and various intermediates formed during degradation under different conditions are summarized. It also includes the general pathway for the degradation of chlorpyrifos. The review will help in the development of tools for degradation and mineralization of organophosphate pesticides by knowing the mechanism of degradation and applicability of the developed process at a large scale.
\end{abstract}

Keywords: Chlorpyrifos, insecticide, degradation pathway, toxicity, intermediates.

\section{INTRODUCTION}

The issue of food security and to provide the food to an ever-increasing global population, the use of pesticides in agriculture has increased after World War II and different types of pesticides belonging to various groups had been developed. The occurrence of residues of these chemicals and their metabolites in every component of the environment, i.e. air, water and soil along with that in the crops, vegetables, and fruits due to their excessive use and emissions during their production poses serious threats to human and environmental health. ${ }^{[1]}$ Pesticides may be neurotoxic, carcinogenic, immunotoxic, etc. and also affect hormonal growth and development. ${ }^{[2-5]}$ Therefore, their removal from the environment is of utmost importance.

The pesticides are sold and used without certain restrictions in most of the developing countries. Although crop production increases on pesticides application as weeds, insects, fungi, rodents, etc are killed, but it affects human health when enter in living organisms through inhalation or consumption of contaminated food and water. ${ }^{[6-8]}$

Pesticides are classified in several ways, i.e. according to their occurrence in nature, their target, and their chemical structure, etc. The different classification of pesticides is summarized in Figure 1.

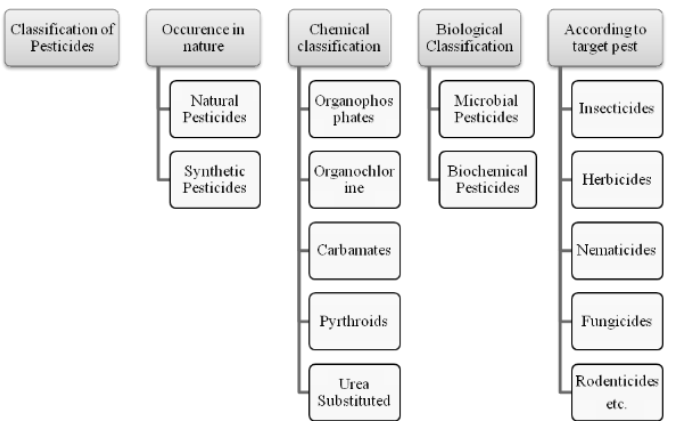

Figure 1. Classification of pesticides.

After the ban on organochlorine pesticides i.e. Dichlorodiphenyltrichloroethane, development of organophosphorus pesticides (OPs), fundamentally esters of phosphoric acids, came into enforced in 1940 due to their low persistence as compared to organochlorine pesticides and high killing efficiency. OPs like malathion, parathion, chlorpyrifos, diazinon, etc. widely used pesticides in agricultural fields, homes, etc., probably due to their low cost, low toxicity, and high effectiveness. OPs, when inhaled in small amounts are tolerable, but above the tolerance limit, it may be fatal. Such instances can occur in the countries where these pesticides are sold and used without certain precautions and regulations to an alarming extent.

4807
The intentional or unintentional inhalation of such pesticides above a certain limit is toxic as they could inhibit the functioning of cholinesterase and causes neurotoxicity. OPs like tetrachlorvinphos and parathion are now recognized as carcinogenic under Group 2B and glyphosate, malathion and diazinon under Group 2A by International Agency for Research on Cancer. ${ }^{[9]}$

Chlorpyrifos [O,O-diethyl O-(3,5,6-trichloro-2-pyridinyl) thiophosphate] (CP), one of the most extensively used broad-spectrum OPs, is sold under various trade names like Dursban, Lorsban etc. It is used throughout the world to control a variety of chewing and sucking insects, flies, mosquitoes, and mites on a range of economically important crops, including cotton, wheat, rice, vegetables, citrus fruit, bananas, potatoes, coffee, cocoa, tea, etc. ${ }^{[10]}$ It is also registered for use on lawns, ornamental plants, domestic dwellings as well as commercial establishments. ${ }^{[11]}$ Chlorpyrifos can persist in soil with a half-life of 60-120 days, however, persistence is observed to be strongly dependant on $\mathrm{pH}$, climate conditions and other factors of soil and it may range from two weeks to more than one year. ${ }^{[11-15]}$ The persistence studies of B.K. Singh and co-workers ${ }^{[16,17]}$ recognized the half-life of CP from 36-46 days in soil. The soil with slightly alkaline $\mathrm{pH}$ was reported to degrade $\mathrm{CP}$ in 90 days. The physical and chemical properties of $\mathrm{CP}$ are depicted in Table [a].

Table [a]. Physical/Chemical properties of CP.

\begin{tabular}{|c|c|c|}
\hline Property & Value & Reference \\
\hline Chemical Name & $\begin{array}{l}\text { O,O-diethyl O-(3,5,6-trichloropyridin-2- } \\
\text { yl) thiophosphate }\end{array}$ & \\
\hline Molecular \& Empirical formula & $\mathrm{C}_{9} \mathrm{H}_{11} \mathrm{C}_{13} \mathrm{NO}_{3} \mathrm{PS}$ & \\
\hline Molecular weight & 350.6 a.m.u. & \\
\hline Trade names & $\begin{array}{l}\text { Dursban }{ }^{\circledR}, \text { Lorsban }{ }^{\circledR}, \text { Empire 20, Equity, } \\
\text { and Whitmire PT } 270\end{array}$ & [18] \\
\hline $\begin{array}{l}\text { Chemical Abstracts Service } \\
\text { number }\end{array}$ & $2921-88-2$ & [18] \\
\hline United Nation number & 2783 & \\
\hline $\begin{array}{l}\text { Globally Harmonized System } \\
\text { number }\end{array}$ & 3 & \\
\hline Chemical number & 59101 & {$[18]$} \\
\hline Physical State & Solid & \\
\hline Colour & White & \\
\hline Melting point & $41-42^{\circ} \mathrm{C}$ & \\
\hline Vapour pressure & $1.87 \times 10^{-5} \mathrm{~mm} \mathrm{Hg}$ at $20^{\circ} \mathrm{C}$ & \\
\hline Odour & Mild Mercaptan & \\
\hline Decomposition temperature & $160^{\circ} \mathrm{C}$ & \\
\hline Solubility in water & Less than $2 \mathrm{mg} \mathrm{L}^{-1}$ at $25^{\circ} \mathrm{C}$ & [11] \\
\hline Log partition coefficient & 4.82-5.11 (Octanol-water) & [142] \\
\hline Acceptable Daily Intake & $0.003 \mathrm{mg} \mathrm{kg}^{-1} \mathrm{~d}^{-1}$ & \\
\hline Maximum Permissible & $0.18 \mathrm{mg} \mathrm{d}^{-1}$ & \\
\hline Intake & & \\
\hline
\end{tabular}

*Corresponding author email: preet2aanand@yahoo.co.in 
Evaluation of United State Environment Protection Agency and Food Quality Protection Act expresses risk to human health and 10X safety factor for children with excessive inhalation of CP. ${ }^{[18]}$ Unfortunately, it shows significant harmful effects on aquatic animals and humans also, when it is present in the high amount by inhibiting the functioning of the enzyme acetylcholinesterase (AcHE) which in turn disrupts the transfer of the message from one neuron to another neuron which may prove to be fatal. ${ }^{[19-20]}$

Literature survey shows that there are reviews on toxicity, ${ }^{[21]}$ food safety of pesticides, ${ }^{[22]}$ bacterial degradation, ${ }^{[23,24]}$ bioremediation of pesticides and petroleum hydrocarbons, [25,26] Photodegradation, [27,28] and pesticide formulations ${ }^{[29]}$ which express the usage, toxic impacts, need and techniques of degradation of the various pesticides. Racke ${ }^{[11]}$ in his review summarized the research information available at that time regarding the environmental fate of chlorpyrifos. To the best of our knowledge, there are no such efforts made on detailing the toxic impacts of $\mathrm{CP}$ on non-target organisms and the induced methods involved in the degradation of $\mathrm{CP}$.

The purpose of this study is to review the toxic effects of $\mathrm{CP}$ on environment and animal health i.e. non-target organisms. Various methods like bacterial degradation, ultrasonication, and photolytic degradation, photocatalytic degradation with $\mathrm{TiO}_{2}, \mathrm{ZnO}$ and $\mathrm{Ag}, \mathrm{Au}, \mathrm{Fe}$ based nanoparticles (NPs), etc. developed for the degradation of the insecticide are also summarized here. Analytical techniques used for the study of degraded products and various intermediates formed during the degradation of $\mathrm{CP}$ are included to establish the general pathway for the degradation of $\mathrm{CP}$ under different conditions.

\section{Toxic Effects of CP}

According to one of the definitions of the insecticide, it is the substance that is poisonous and efficient to target organisms and is safe to non-target organisms and the environment. As CP is not selective in nature, therefore the poisonous nature of $\mathrm{CP}$ is not only restricted to target organisms, but it also shows paramount toxic effects on non-target organisms including humans, even at low concentrations. The insecticidal action of $\mathrm{CP}$ involves the inhibition in the functioning of AcHE and the insect undergoes decomposition and commences to decay slowly.

$\mathrm{CP}$ present in the environmental matrices undergoes oxidation and $\mathrm{CP}(\mathrm{P}=\mathrm{S})$ is converted into $\mathrm{CP}(\mathrm{P}=\mathrm{O})$ i.e. chlorpyrifos-oxon $(\mathrm{CPO})$ which is found to be more toxic than $\mathrm{CP}$ itself. Oxidation of $\mathrm{CP}$ to $\mathrm{CPO}$ is enhanced by the presence of $\mathrm{OH}$ radicals in atmospheric conditions. ${ }^{[30]}$ The structure of $\mathrm{CP}$ and $\mathrm{CPO}$ is shown in Figure 2(a) and 2(b)<smiles>CCOP(=S)(OCC)Oc1nc(Cl)c(Cl)cc1Cl</smiles>

(a)

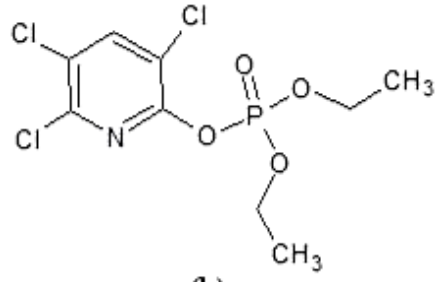

(b)
Figure 2. Structure of (a) Chlorpyrifos (b) Chlorpyrifos-oxon.

Chlorpyrifos is very harmful to various life forms even at a very low concentration and can kill aquatic animals. The toxic effects of $\mathrm{CP}$ at a low concentration has been confirmed through tests and studies performed on various animals.

The significant inhibition in the activity of enzyme AcHE with exposure at a low concentration of $\mathrm{CP}$ in combination with $\mathrm{CPO}$ is reported. ${ }^{\left[{ }^{[1]}\right.}$ The study also reported that 3,5,6-trichloropyridinol (TCP) did not show significant inhibition in enzyme activity. The toxic effects of $\mathrm{CP}$ on zebrafish for short and long term exposure of different doses of $\mathrm{CP}(5 \mu \mathrm{M}$ and $2 \mu \mathrm{M})$ had been observed by Canela et al. ${ }^{[32]}$ The higher dose of $\mathrm{CP}$ produced greater variations in zebrafish muscles as compared to a lesser dose. However, no direct relation of time with toxicity was observed. The results obtained after continues observation on zebrafish muscle confirmed oxidative stress, disruption of neurotransmitter metabolism, and muscle exhaustion in zebrafish. Yen et al. ${ }^{[19]}$ reported the inhibition of AcHE activity and a simultaneous decrease in locomotor activity in zebrafish at a low concentration of CP. Mccollister et al. ${ }^{[33]}$ observed not only inhibition of AcHE but also in the activity of brain and plasma cholinesterase which might have been recovered with time. Similar recovery results were observed in studies of Drevenkar et al. ${ }^{[34]}$ when erythrocyte AcHE and blood cholinesterase activities were measured in serum and urine of persons exposed with chlorpyrifos. The studies ${ }^{[35-37]}$ reported significant inhibition by chlorpyrifos in plasma cholinesterase, butyrylcholinesterase and in gammarus pulex AcHE activity.

Various studies ${ }^{[38-40]}$ on fish and mice are reported to prove significant oxidative stress on the exposure of CP. CP alone results in 2-deoxyribosenucleic acid (DNA) damage but presence of lipopolysaccharides along with $\mathrm{CP}$ enhances damage even at a low concentration, as found in fish Gasterosteus aculeeatus. ${ }^{[41]}$ The variation in the concentration of insecticide delays the effect produced by insecticide on Japanese medaka. The introduction of a sublethal concentration of CP for a longer period and a lethal concentration for shorter period cause similar variation in social behavior. However, inhibition in blood cholinesterase activity was not observed with sublethal concentration. ${ }^{[42]}$

Significant inhibition and variations are observed on the behavior of rats even at the exposure of low concentration of $\mathrm{CP}$. The variation in Ribose nucleic acid (RNA) concentration of rats in the brainstem was more prominent than in the forebrain. ${ }^{[43]}$ Young animals are more sensitive as compared to adult animals with exposure to $\mathrm{CP}$ and a faster recovery was reported in young rats. ${ }^{[44]}$ The neonatal rats are highly sensitive towards plasma and brain cholinesterase activity. ${ }^{[45,46]}$ The concentration dependent inhibition in the normal movement of membrane bound organelles in the presence of $\mathrm{CP}$ at higher concentrations. ${ }^{[47]}$ The studies ${ }^{[48-52]}$ over rats give suitable evidence for the toxic nature of $\mathrm{CP}$ and reported the anxiety in rats during the pregnancy period, oxidative stress, anti-androgenic activity, and cholinesterase inhibition, and the changes in the functioning of brain cells.

$\mathrm{CP}$ shows disease toxicant interaction with mutant huntingtin. The mutant enhances the neurotoxicity induced by $\mathrm{CP}$ with the increase in the production of reactive oxygen species and nicotinamide adenine dinucleotide phosphate (NADPH) oxidase activity. The study recognized that CP-induced toxicity is enhanced via NADPH oxidase-mediated oxidative stress. ${ }^{[53]}$ Dubey et al. ${ }^{[54]}$ observed the effect of $\mathrm{CP}$ and fungicide propiconazole on barley (Hordeum vulgare L. variety Karan-16). CP showed more increase in the chromosomal aberrations and more reduction of the germination percentage as compared to propiconazole, which indicates a high ability of $\mathrm{CP}$ to cause genotoxicity on barley.

Fernandes et al. ${ }^{[55]}$ studied the effect of different concentrations $(0-0.08 \% \mathrm{w} / \mathrm{v})$ of $\mathrm{CP}$ on the growth of green bean plants (Phaseolus vulgaris). Plants treated with a higher dose of $\mathrm{CP}$ resulted in the smaller size of leaves, and a reduction in the number of pods after 45 days of treatment. It could affect the yield of crops also. Along with induced oxidative stress, changes in lipid concentration, decrease in triacylglycerol content was observed and such changes could affect the nutritional value.

From the above studies it can be concluded that $\mathrm{CP}$ is harmful to humans and animals and due to its neurotoxic nature, it is supposed to be health hazardous for all living organisms. ${ }^{[56-58]}$ However, Zhang et al. ${ }^{[59]}$ reported that if chlorpyrifos is present below the maximum residual limit, then it does not produce any harmful effects and it shows useful applications at specific conditions. The toxic nature of chlorpyrifos increases in the presence of pesticides like chlorothalonil. ${ }^{[14]}$ Besides showing such harmful effects, chlorpyrifos also inhibits the progress of the brain, affects the cell shape and growth of cell organelles, and inhibits carboxylsterase activity of the soil, catalase and dehydrogenase activity in the soil. ${ }^{[60-63]}$

Apart from above toxic affects the high concentration of $\mathrm{CP}$ inhibited the growth and amount of chlorophyll $a{ }^{[64]}$ The inhibitory effects on reproduction and survival of springtail folsomia candida also give evidence for the toxicity of CP. ${ }^{\left[{ }^{65]}\right.}$ Various studies on the toxic effects of $\mathrm{CP}$ in different organisms are summarized in Table [b]. 
Table [b]. Toxic effects of CP.

\begin{tabular}{|c|c|c|c|c|}
\hline $\begin{array}{l}\text { Sr. } \\
\text { No. }\end{array}$ & System & $\begin{array}{c}\text { Concentration } \\
\text { of CP }\end{array}$ & Comments on toxicity & Reference \\
\hline 1. & Zebrafish & $300 \mathrm{nM}$ & $\begin{array}{l}\text { Inhibited AcHE and } \\
\text { locomoter activity }\end{array}$ & [14] \\
\hline 2. & Human & - & $\begin{array}{l}\begin{array}{l}\text { Blood Cholinesterase } \\
\text { activity effected }\end{array} \\
\end{array}$ & {$[34]$} \\
\hline 3. & Zebrafish & $100-300 \mu \mathrm{g} \mathrm{L}^{-1}$ & $\begin{array}{l}\text { Developmental toxicity, } \\
\text { Oxidative stress, } \\
\text { Neurotoxicity, } \\
\text { locomoter activity }\end{array}$ & {$[38]$} \\
\hline 4. & $\begin{array}{l}\text { Mice lacking glutamate } \\
\text { cysteine ligase }\end{array}$ & - & $\begin{array}{l}\text { Oxidative stress and } \\
\text { cytotoxicity }\end{array}$ & [39] \\
\hline 5. & $\begin{array}{l}\text { Three spined stickleback } \\
\text { (Gasterosteus } \\
\text { aculeeatus) }\end{array}$ & $\begin{array}{l}1.75,0.88, \\
0.35,0.18,0 \mu \mathrm{g} \\
\mathrm{L}^{-1}\end{array}$ & $\begin{array}{l}\text { Lipopolysaccharides } \\
\text { enhanced DNA damage }\end{array}$ & [41] \\
\hline 6. & $\begin{array}{l}\text { Japanese medaka } \\
\text { (Oryziaslatipes) }\end{array}$ & $\begin{array}{l}0.12 \mathrm{mg} \mathrm{L}^{-1} \\
\text { (lethal) } \\
0.012 \mathrm{mg} \mathrm{L}^{-1} \\
\text { (sub- lethal) }\end{array}$ & $\begin{array}{l}\text { Decrease in Social } \\
\text { behavior in } 12 \text { days with } \\
\text { sub-lethal concentration } \\
\text { was similar in } 4 \text { days } \\
\text { with lethal }\end{array}$ & [42] \\
\hline 7. & Rats & $\begin{array}{l}1 \mathrm{mg} \mathrm{kg}^{-1} \text { (days } \\
1-4 \text { ) and } 5 \mathrm{mg} \\
\mathrm{kg}^{-1} \text { (days } 11- \\
14 \text { ) }\end{array}$ & $\begin{array}{l}\text { Effected RNA } \\
\text { Concentration and } \\
\text { showed delayed } \\
\text { neurotoxicity }\end{array}$ & [43] \\
\hline 8. & Rats & $\begin{array}{l}\text { Young rats, } 15 \\
\mathrm{mg} \mathrm{kg}^{-1} \\
\text { Adult rats, } 80 \\
\mathrm{mg} \mathrm{kg}^{-1}\end{array}$ & $\begin{array}{l}\text { Behavioral changes and } \\
\text { Brain and Blood } \mathrm{ChE} \\
\text { inhibition. Young } \\
\text { animals are more } \\
\text { sensitive than adult. }\end{array}$ & [44] \\
\hline 9. & Rats & - & $\begin{array}{l}\text { Body weight Reduction } \\
\text { and cholinesterase } \\
\text { inhibition in neo-natal } \\
\text { rat is more sensitive }\end{array}$ & [46] \\
\hline 10. & Rats & $0.1 \mathrm{nM}-10 \mu \mathrm{M}$ & $\begin{array}{l}\text { Higher doses inhibited } \\
\text { the movement of blood } \\
\text { circulation in axons }\end{array}$ & [47] \\
\hline 11. & Offspring rats & $\begin{array}{l}0.1-10 \mathrm{mg} \mathrm{kg}^{-1} \\
\mathrm{~d}^{-1}\end{array}$ & $\begin{array}{l}\text { Even low concentration } \\
\text { of } \mathrm{CP} \text { causes anxiety in } \\
\text { rats during pregnancy }\end{array}$ & [48] \\
\hline 12. & Wistar Rats & $10 \mathrm{mg} \mathrm{kg}^{-1}$ & $\begin{array}{l}\text { Changes in spleen } \\
\text { weight, Thymus } \\
\text { Atrophy, Splenomegaly } \\
\text { and Oxidative stress }\end{array}$ & [49] \\
\hline 13. & Rats & $2-250 \mathrm{mg} \mathrm{kg}^{-1}$ & Anti-androgenic activity & {$[50]$} \\
\hline 14. & Rats & $\begin{array}{l}0.4-40 \mathrm{mg} \mathrm{kg}^{-1} \\
\text { (CPO) }\end{array}$ & $\begin{array}{l}\text { Cholinesterase } \\
\text { inhibition }\end{array}$ & [51] \\
\hline 15. & Neonatal Rats & $1 \mathrm{mg} \mathrm{kg}^{-1} \mathrm{~d}^{-1}$ & $\begin{array}{l}\text { Permanent changes in } \\
\text { brain cell }\end{array}$ & {$[52]$} \\
\hline 16. & $\begin{array}{l}\text { Green Algae } \\
\text { (Ankistrodesmusgracilis) }\end{array}$ & $\begin{array}{l}9.37-150 \mathrm{mg} \\
\mathrm{L}^{-1}\end{array}$ & $\begin{array}{l}\text { Inhibited the growth and } \\
\text { cell shape of cell } \\
\text { organelles at high } \\
\text { concentration }\end{array}$ & [61] \\
\hline 17. & Soil & $10 \mathrm{mg} \mathrm{kg}^{-1}$ & $\begin{array}{l}\text { Inhibition of } \\
\text { carboxylesterase } \\
\text { activity }\end{array}$ & {$[62]$} \\
\hline 18. & Soil & ${ }_{1}^{4.8 \& 24 \mathrm{~kg} \mathrm{ha}^{-}}$ & $\begin{array}{l}\text { Strong inhibition of } \\
\text { hydrolases and } \\
\text { oxidoreductases }\end{array}$ & [63] \\
\hline 19. & $\begin{array}{l}\text { Freshwater Microalgaes } \\
\text { Chlorella pyrenoidosa } \\
\text { and Merismopediasp }\end{array}$ & $0-100 \mathrm{mg} \mathrm{L}^{-1}$ & $\begin{array}{l}\text { Inhibited the growth, } \\
\text { and content of } \\
\text { Chlorophyll } a \text { at high } \\
\text { concentration }\end{array}$ & [143] \\
\hline 20. & Mice & $\begin{array}{l}0.28-8.96 \mathrm{mg} \\
\mathrm{kg}^{-1}\end{array}$ & DNA damage & {$[144]$} \\
\hline
\end{tabular}

The toxic effects of $\mathrm{CP}$ are not only observed in target organisms but the effects are also seen in non-target organisms including humans and animals. Moreover, due to properties of CP i.e. low water solubility and soil sorption, intensive and repetition applications in agriculture crops may result in the accumulation of its residue. Consequently, the increased residue of the insecticide in the soil interferes with the functional properties of beneficial soil microbes i.e. plant growth-promoting microbes (PGPM), which play a crucial role in enhancing plant growth and improving soil fertility. ${ }^{[6]} \mathrm{CP}$ also suppressed nodulation in chickpea and specific rhizobial counts in the crop rhizosphere. ${ }^{[67]}$
So it is necessary to degrade CP from the environment. Some of the major methods used so far for the degradation of $\mathrm{CP}$ and the techniques used for the analysis of residual $\mathrm{CP}$ and its degraded products were discussed in this paper.

\section{Degradation of CP}

The above studies reveal the toxic impact of $\mathrm{CP}$ and its potential to produce harmful effects on non-target organisms, even serious damage to human health and other organisms in the environment. There is a need to degrade the $\mathrm{CP} / \mathrm{CP}$ residues from the environment. The degraded products of chlorpyrifos should be non-toxic or less toxic than chlorpyrifos itself. However, Chlorpyrifos-oxon, which is a major metabolite of chlorpyrifos, is much more toxic than chlorpyrifos itself. ${ }^{[68]}$ So an analysis of degraded products is also important. Various methods and techniques are used for the degradation of CP and degraded products/intermediates of $\mathrm{CP}$ under different conditions. Such studies along with possible degradation products of $\mathrm{CP}$ are summarized below.

\section{Natural degradation}

Chlorpyrifos in the environment undergoes adsorption, hydrolysis, oxidation or photolysis. The photolytic experiment involves direct treatment of $\mathrm{CP}$ in sunlight or ultraviolet (UV) light from water or soil. The photolysis of CP from soil solutions in acidic and alkaline medium at different temperatures in UV and sunlight is reported. Alkaline conditions ( $\mathrm{pH} 8$ ) caused higher degradation than acidic conditions ( $\mathrm{pH}$ 6). The degradation rate was higher at high temperature $\left(40^{\circ} \mathrm{C}\right)$ than at low temperature $\left(22^{\circ} \mathrm{C}\right)$. Moreover, the study was extended to check the influence of various metal ions. The presence of $0.01 \mathrm{M} \mathrm{Ca}^{2+}$ and $\mathrm{K}^{+}$ enhanced solar degradation, however, $0.1 \mathrm{M} \mathrm{Mg}^{2+}$ and $\mathrm{PO}_{4}{ }^{3-}$ enhanced UV degradation. ${ }^{[69]}$

CPO and TCP are major metabolites of CP during its photolysis under UV radiation. These metabolites are more water-soluble than $\mathrm{CP}$ itself and thus show greater field mobility. ${ }^{[70]}$ The photolysis of $\mathrm{CP}$ also confirmed that soil with higher organic matter enhances the rate constant during photolysis. In this study medium pressure, $\mathrm{Hg}$ Lamp was used for photolysis and it was found to be more effective than xenon lamp or low-pressure Hg Lamp. TCP was observed to be formed as a major metabolite. ${ }^{[71]}$ Identical intermediate was identified during photolysis with Xe arc lamp. ${ }^{\text {[72] }}$

The rapid degradation of the pesticide in the presence of NOx forms various multi oxygenated products and most of the products retained their pyridine ring. The degradation of $\mathrm{CP}$ under atmospheric conditions indicates the formation of $\mathrm{CPO}$ on oxidation in the presence of $\mathrm{OH}$ radicals. It is reported that the atmospheric lifetime of CP (2 hrs) is less than CPO (11 hrs). ${ }^{[30,73]}$

\section{Biodegradation}

Biodegradation involves the breakdown of large and complex substances to small and simple molecules, which are less toxic or non-toxic than their respective parent substances, with the help of microorganisms like fungi, bacteria, etc. A wide range of pesticides, present in the environment, are slowly degraded by microorganisms. As this process is economical and efficient, so, continued efforts are being done to increase the degradation ability of microorganisms. Several microorganisms are isolated for the degradation of CP. The use of microorganisms for degradation of $\mathrm{CP}$ in soil and water is an efficient method. During degradation, two major intermediates TCP and diethylphosphate (DEP) are detected, their structures are shown in Figure 3.<smiles>[O-]c1nc(Cl)c(Cl)cc1Cl</smiles>

(a)

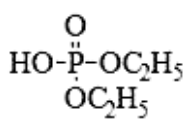

(b)
Figure 3. Structure of (a) TCP and (b) DEP.

These metabolites are further degraded into simpler organic and inorganic substances. The review on degradation ability of pseudomonas species for chlorpyrifos suggests that these species have the highest capacity to degrade chlorpyrifos and its metabolites TCP and DEP to nontoxic compounds like $\mathrm{CO}_{2}$, $\mathrm{H}_{2} \mathrm{O}$ etc. and out of various pseudomonas species, $p$. putida MAS- 1 is reported to be more efficient. ${ }^{[74]}$ The various microorganisms which have shown high efficacy in biodegradation are listed in Table $[c]$. 
Table [c]. Various microorganisms used for bacterial degradation of CP.

\begin{tabular}{|c|c|c|c|c|c|c|c|}
\hline $\begin{array}{l}\text { Sr. } \\
\text { No. }\end{array}$ & Microorganism & $\begin{array}{c}\text { Concentration of } \\
\text { CP }\end{array}$ & $\begin{array}{c}\text { \%age } \\
\text { degradation }\end{array}$ & Degradation time & $\begin{array}{c}\text { Optimum } \\
\text { temperature }\end{array}$ & Optimum pH & Reference \\
\hline 1 & Pseudomonas (Iso 1) sp & $500 \mathrm{mg} \mathrm{L}^{-1}$ & $>90 \%$ & - & $37^{\circ} \mathrm{C}$ & 7.5 & [75] \\
\hline 2 & Pseudomonas putida & $50 \mathrm{mg} \mathrm{L}^{-1}$ & $>97 \%$ & $3 \mathrm{~h}$ & $25^{\circ} \mathrm{C}$ & 3 & [76] \\
\hline 3 & B. safensis strain $F O-36 b^{T}$ & $400 \mathrm{mg} \mathrm{L}^{-1}$ & $62-89 \%$ & $\begin{array}{l}14 \mathrm{~d} \text { (maximum } \\
\text { degradation) }\end{array}$ & $25^{\circ} \mathrm{C}$ & - & {$[78]$} \\
\hline 4 & $\begin{array}{lccc}\text { B. } \quad \text { subtilis } & \text { subsp. inaquosorum strain } \\
\text { KCTC } 13429^{T} & & \end{array}$ & $400 \mathrm{mg} \mathrm{L}^{-1}$ & $39-89 \%$ & $\begin{array}{l}14 \mathrm{~d} \text { (maximum } \\
\text { degradation) }\end{array}$ & $25^{\circ} \mathrm{C}$ & - & {$[78]$} \\
\hline 5 & B. cereus strain ATCC14579 & $400 \mathrm{mg} \mathrm{L}^{-1}$ & $38-87 \%$ & $\begin{array}{c}14 \mathrm{~d} \text { (maximum } \\
\text { degradation) }\end{array}$ & $25^{\circ} \mathrm{C}$ & - & [78] \\
\hline 6 & Bacillus subtilis Strain, Y242 & $150 \mathrm{mg} \mathrm{L}^{-1}$ & $95.12 \%$ & $48 \mathrm{~h}$ & - & 8 & [79] \\
\hline 7 & Bacillus pumilus strain $C 2 A 1$ in $M S M$ & $100-1000 \mathrm{mg} \mathrm{L}^{-1}$ & $73-89 \%$ & $2 \mathrm{~d}-2$ weeks & $\begin{array}{l}37^{\circ} \mathrm{C}(\exp \\
\text { performed })\end{array}$ & $\begin{array}{c}8.5(\text { for } 50 \mathrm{mg} \\
\left.\mathrm{L}^{-1}\right)\end{array}$ & {$[81]$} \\
\hline 8 & Alcaligenes faecalis Strain DSP 3 & $500 \mathrm{mg} \mathrm{L}^{-1}$ & $>90 \%$ & $10 \mathrm{~d}$ & $30^{\circ} \mathrm{C}$ & 8 & {$[82]$} \\
\hline 9 & Brucella melitensis M19 & $50 \mathrm{mg} \mathrm{L}^{-1}$ & $87 \%$ & $30 \mathrm{~d}$ & - & - & [84] \\
\hline 10 & Bacillus subtilis, M119 & $50 \mathrm{mg} \mathrm{L}^{-1}$ & $85 \%$ & $30 \mathrm{~d}$ & - & - & [84] \\
\hline 11 & Bacillus cereus, D113 & $50 \mathrm{mg} \mathrm{L}^{-1}$ & - & $20 \mathrm{~d}$ & - & - & [84] \\
\hline 12 & Klebsiella Species, $Q 1 a / Q 2 a$ & $50 \mathrm{mg} \mathrm{L}^{-1}$ & $77 \%-81 \%$ & $20 \mathrm{~d}$ & - & - & {$[84]$} \\
\hline 13 & Serratia marcescens, $Q 2 b$ & $50 \mathrm{mg} \mathrm{L}^{-1}$ & $80 \%$ & $20 \mathrm{~d}$ & - & - & [84] \\
\hline 14 & Paeroginosa, Q2c & $50 \mathrm{mg} \mathrm{L}^{-1}$ & $84 \%$ & $20 \mathrm{~d}$ & - & - & [84] \\
\hline 15 & P. Fluorescence, $P$ & $50 \mathrm{mg} \mathrm{L}^{-1}$ & $89 \%$ & $30 \mathrm{~d}$ & - & - & [84] \\
\hline 16 & Acremonium sp. strain $(G F R C-1)$ & $300 \mathrm{mg} \mathrm{L}^{-1}$ & $83.9 \%$ & $20 \mathrm{~d}$ & $30^{\circ} \mathrm{C}$ & - & {$[85]$} \\
\hline 17 & Enterobacter strain B-14 & $25 \mathrm{mg} \mathrm{L}^{-1}$ & $\begin{array}{c}\text { Complete } \\
\text { degradation }\end{array}$ & $2 \mathrm{~d}$ & $35^{\circ} \mathrm{C}$ & $5.5-7.6$ & [86] \\
\hline 18 & Paracoccus sp. & $50 \mathrm{mg} \mathrm{L}^{-1}$ & $100 \%$ & $4 \mathrm{~d}$ & $35^{\circ} \mathrm{C}$ & 8 & [87] \\
\hline 19 & Actinobacteria & $50 \mathrm{mg} \mathrm{L}^{-1}$ & $92 \%$ & $24 \mathrm{~h}$ & - & - & {$[88]$} \\
\hline 20 & Cupriavidus sp. DT-1, & $100 \mathrm{mg} \mathrm{L}^{-1}$ & $>90 \%$ & $\begin{array}{l}14 \mathrm{~h} \text { (Liquid) } \\
30 \mathrm{~d} \text { (Soil) }\end{array}$ & $30^{\circ} \mathrm{C}$ & 7 & [89] \\
\hline 21 & Cyperus alternifolius plant and Fe biochar & $380.3 \pm 2.1 \mu \mathrm{g} \mathrm{L}^{-1}$ & $>99 \%$ & $\begin{array}{l}50 \mathrm{~d} \text { (maximum } \\
\text { degradation) }\end{array}$ & - & - & [92] \\
\hline 22 & $\begin{array}{l}\text { Cladosporium cladosporioides } \\
\mathrm{Hu}-\mathrm{Ol}\end{array}$ & $50 \mathrm{mg} \mathrm{L}^{-1}$ & $>90 \%$ & $5 \mathrm{~d}$ & $40^{\circ} \mathrm{C}$ & 6.5 & [93] \\
\hline 23 & Sphigomonas sp. strain Dsp-2 & $100 \mathrm{mg} \mathrm{kg}^{-1}$ & $98.7 \%$ & $7 \mathrm{~d}$ & - & 8.7 & [94] \\
\hline 24 & Mesorhizobium sp. HN3 & $400 \mathrm{mg} \mathrm{L}^{-1}$ & $\begin{array}{c}\text { Complete } \\
\text { degradation }\end{array}$ & 10 & $37^{\circ} \mathrm{C}$ & 7 & [97] \\
\hline 25 & Ochrobactrum sp. JAS2 & $300 \mathrm{mg} \mathrm{L}^{-1}$ & $\begin{array}{c}\text { Complete } \\
\text { degradation }\end{array}$ & $4 d$ & $30^{\circ} \mathrm{C}$ & - & [99] \\
\hline
\end{tabular}

The pseudomonas (Iso 1) sp. has degraded more than $90 \%$ for high initial concentration of $\mathrm{CP}\left(500 \mathrm{mg} \mathrm{L}^{-1}\right)$ in bioreactors packed with polyurethane foam at $\mathrm{pH} 7.5$ and temperature $37^{\circ} \mathrm{C}$. ${ }^{[75]}$ The pseudomonas putida MB 285 cells degraded $95 \%$ of CP $\left(50 \mathrm{mg} \mathrm{L}^{-1}\right)$ is observed in $3 \mathrm{hrs}$ only. A wide range of temperature and $\mathrm{pH}$ were investigated during degradation, temperature $25^{\circ} \mathrm{C}$ and $\mathrm{pH} 3$ was found to be optimum. ${ }^{[76]}$

Pseudomonas $\mathrm{Sp}$. has shown a high tendency for degradation of CP; however, other bacterial strains like bacillus and agrobacterium sp. have also been reported to produce comparable degradation efficiency. ${ }^{[77]}$ The degradation capacity of three bacterial strains i.e. bacillus safensis strain FO-36bT, bacillus subtilis subsp. inaquosorum strain KCTC13429T, and bacillus cereus strain ATCC14579T was investigated in pesticide polluted soil of sudan. B. Safensis showed maximum degradation percentage $(62-89 \%)$ for $\mathrm{CP}$. TCP, a major metabolite of $\mathrm{CP}$, was identified during degradation with $b$. Safensis only, whereas other bacterial strains did not show the formation of such intermediates after 14 days of incubation at $25^{\circ} \mathrm{C}$ in a mineral salt medium. ${ }^{[78]}$

Bacillus subtilis Y242 has shown the potential to utilize CP $\left(150 \mathrm{mg} \mathrm{L}^{-1}\right)$ as a carbon source under alkaline medium. Lower concentration of CP $\left(50 \mathrm{mg} \mathrm{L}^{-1}\right)$ 
was degraded completely after $24 \mathrm{hrs}$ but a higher concentration of CP $(150 \mathrm{mg}$ $\mathrm{L}^{-1}$ ) was degraded up to $95.12 \%$ even after $48 \mathrm{hrs} .{ }^{[79]}$ Bacillus cereus MCAS 02 degraded $89 \%$ of $\mathrm{CP}\left(50 \mathrm{mg} \mathrm{L}^{-1}\right)$ under optimum conditions $\mathrm{pH} 7.5$, shaking speed $90 \mathrm{rpm}$, temperature $32^{\circ} \mathrm{C}$ and yeast extract concentration $2.5 \mathrm{~g} \mathrm{~L}^{-1}$ was observed. ${ }^{80]}$

Bacillus strain $C 2 A 1{ }^{[81]}$ and alcaligenes faecalis ${ }^{[82]}$ had been prospered to degrade CP under alkaline medium. Bacillus Strain C2A1 has shown 89\% degradation of high concentration of $\mathrm{CP}\left(1000 \mathrm{mg} \mathrm{L}^{-1}\right)$ in a liquid medium within 15 days under alkaline medium at $37^{\circ} \mathrm{C}$ temperature. Bacillus pumilus strain $C 2 A I^{[83]}$ had shown a higher potential to degrade $\mathrm{CP}$ and its metabolite TCP when bacterial strain is inoculated with plant ryegrass. Plant bacteria partnership enhanced degradation of $\mathrm{CP}\left(50 \mathrm{mg} \mathrm{kg}^{-1}\right)$ to $97.5 \%$ whereas with alone plant and alone ryegrass only $89 \%$ and $76 \%$ degradation was achieved after 45 days of incubation, respectively. CP $\left(50 \mathrm{mg} \mathrm{kg}^{-1}\right)$ has been degraded $75-87 \%$ with pseudomonas fluorescence, brucella melitensis, bacillus subtilis, bacillus cereus, klebsiella species, serratia marcescens and pseudomonas aeroginosa as consortium. However, p. aeroginosa showed $92 \%$ degradation when applied individually. ${ }^{[84]}$

The fungal degradation of $\mathrm{CP}\left(300 \mathrm{mg} \mathrm{L}^{-1}\right)$ with acremonium sp. strain (GFRC-1) in soil enriched with carbon and nitrogen. Nearly, $84 \%$ degradation is achieved in 20 days. ${ }^{[85]}$ The enterobacter strain $B-14$ utilized CP as a sole source of carbon and phosphorus. The degradation was complete in nearly 2 days at temperature $35^{\circ} \mathrm{C}$ in mineral salt medium inoculated with nitrogen. The addition of glucose and succinate delayed the degradation process. However, no significant effect of $\mathrm{pH}$ was observed. ${ }^{[86]}$ The studies also demonstrate the formation of intermediates DEP and TCP.

Nearly complete degradation of $\mathrm{CP}\left(50 \mathrm{mg} \mathrm{L}^{-1}\right)$ with paracoccus species under slightly alkaline medium, i.e. $\mathrm{pH} 8$ and temperature $35^{\circ} \mathrm{C} .{ }^{[87]}$ Similarly, actinobacteria strains have also been found useful for this purpose where proximately $90 \%$ degradation is reported after $24 \mathrm{hrs.}{ }^{[88]}$

The cupriavidus sp. DT-1 had shown the potential to degrade CP and TCP in both liquid and soil medium using them as a sole source of carbon. CP $(100 \mathrm{mg}$ $\mathrm{L}^{-1}$ ) along with its metabolite TCP is found to be completely degraded by strain $D T-1$ in the liquid medium after only $14 \mathrm{hrs}$ under neutral $\mathrm{pH}$ and $30^{\circ} \mathrm{C}$ temperature. The strain has also shown more than $90 \%$ degradation of $\mathrm{CP}$ in the soil after 30 days. ${ }^{[89]}$ Bacterial strain stenotrophomonas sp. G1 species degraded $63 \%$ of $\mathrm{CP}\left(50 \mathrm{mg} \mathrm{L}^{-1}\right)$ at temperature $40^{\circ} \mathrm{C}$. This strain not only degraded $\mathrm{CP}$ but also other OP's like methyl parathion, diazinon, phoxim, profenofos and triazaphos, parathion, methyl paraoxon effectively under similar conditions. ${ }^{[90]}$

The plant cyperus alternifolius and Fe-impregnated biochar have been reported to enhance the degradation of CP. ${ }^{[91,92]}$ Studies of Gao et al. ${ }^{[93]}$ reported more than $90 \%$ of $\mathrm{CP}\left(50 \mathrm{mg} \mathrm{L}^{-1}\right)$ degraded in 5 days with cladosporium cladosporioides $\mathrm{Hu}-1$. The enzyme has shown maximum hydrolase activity at $\mathrm{pH} 6.5$ and temperature $40^{\circ} \mathrm{C}$. The activity of the enzyme was examined in the presence of metal ions like $\mathrm{Hg}^{2+}, \mathrm{Fe}^{3+}, \mathrm{Zn}^{2+}, \mathrm{Cu}^{2+}, \mathrm{Mn}^{2+}$, and $\mathrm{Mg}^{2+}$. The strong inhibition of activity was observed with $\mathrm{Hg}^{2+}$ and $\mathrm{Fe}^{3+}$, while other metal ions showed only $5-10 \%$ inhibition.

The sphingomonas sp. strain Dsp-2 rapidly degraded CP in alkaline medium. $\mathrm{CP}\left(100 \mathrm{mg} \mathrm{kg}^{-1}\right)$ was degraded up to $98.7 \%$ in soil with $\mathrm{pH} 8.7$. However, only $58.1 \%$ degradation was achieved in soil with $\mathrm{pH} 4.8$ and $90 \%$ degradation was achieved in the neutral medium after first 7 days. In cell culture, CP $\left(100 \mathrm{mg} \mathrm{L}^{-}\right.$ ${ }^{1}$ ) was degraded completely in $24 \mathrm{hrs}$ only, but its metabolite TCP was degraded only upto $30 \mathrm{mg} \mathrm{L}^{-1}$ after $48 \mathrm{hrs}$ of treatment at $30^{\circ} \mathrm{C}$. ${ }^{[94]}$

$\mathrm{CP}$ has a high potential for adsorption in the soil as compared to triagophos and TCP also in the paddy field of China. It indicates lesser partitioning of $\mathrm{CP}$ in water as compared to soil. This study was extended to observe the degradation capacity of bacterial strain diaphorobacter sp. GS-1. Complete degradation of CP was obtained after 21 days of inoculation in soil. ${ }^{[95]}$ The adsorption of CP in soil has a direct relation with soil organic matter. ${ }^{\left[{ }^{[9]}\right.}$ The study also reveals that the adsorption of $\mathrm{CP}$ was high at lower $\mathrm{pH}$.

Complete degradation of high concentration of $\mathrm{CP}\left(400 \mathrm{mg} \mathrm{L}^{-1}\right)$ is with bacterial strain mesorhizobium sp. HN3 in 10 days. Among the wide range of $\mathrm{pH}$ and temperature conditions, maximum degradation was observed at $\mathrm{pH} 7$ and temperature $37^{\circ} \mathrm{C}$. Under similar conditions of $\mathrm{pH}$ and temperature, $\mathrm{CP}(100 \mathrm{mg}$
$\mathrm{L}^{-1}$ ) was degraded only in 5 days. ${ }^{[97]}$ The bacterial strain sphingobacterium $s p$. $J A S 3$ had shown the ability to degrade CP $\left(300 \mathrm{mg} \mathrm{L}^{-1}\right)$ and TCP also within 5 days of incubation. ${ }^{[98]}$ Whereas, the bacterial strain ochrobactrum sp. JAS2 degraded CP $\left(300 \mathrm{mg} \mathrm{L}^{-1}\right)$ and TCP in an aqueous medium within 4 days of incubation. TCP was also completely degraded in both soil and aqueous medium. However, degradation in soil without enriched by nutrients was slower than soil enriched with nutrients. ${ }^{[99]}$ Akbar et al. ${ }^{[100]}$ observed $78.6 \%$ and $84.4 \%$ degradation of CP $\left(100 \mathrm{mg} \mathrm{L}^{-1}\right)$ with two bacterial strains ochrobactrum sp. FCp1 and achromobacter xylosoxidans JCp4 respectively in a liquid medium within 10 days and more than $93 \%$ degradation of $\mathrm{CP}\left(200 \mathrm{mg} \mathrm{kg}^{-1}\right)$ in sterilized and non-sterilized soil after 42 days. Degradation is found to be enhanced in unsterilized soil.

The above studies reveal that $\mathrm{CP}$ is effectively degraded with the help of various microbes and degradation can be enhanced with certain bacterias which can utilize $\mathrm{CP}$ as a sole source of carbon or phosphorous under optimum $\mathrm{pH}$ and temperature. One of the drawbacks of extensive use of the insecticide is the loss of beneficial microbial diversity. ${ }^{[101]}$ Therefore, research on the effect of pesticides on microbial community dynamics should not be neglected to have background information. ${ }^{[102]}$

Hence genome sequence of the PGPM, which have tolerance or degradation ability towards organophosphate insecticide and promotes seed germination of vegetable even under insecticide stress should be known. Recently, several studies have indicated that native PGPM consortium enhances plant growth in the presence of residual OP insecticide and also has the capability to remediate pesticide-contaminated soils. ${ }^{[101,103-105]}$

A recent study on Brinjal, Tomato, and Okra vegetables reported that excessive application of $\mathrm{CP}$ on vegetables can be harmful. The study also reported that the presence of organophosphate degrading opdA and opd genes in strain bacillus licheniformis (BHUJP-P3) and bacillus cereus (BHUJP-P4), degrade 53 and $90 \% \mathrm{CP}$ of (50 mg kg $\left.\mathrm{g}^{-1}\right)$, respectively in 3 days only and can decrease its toxic effects on seed germination. The presence of such genes can enhance vegetable production and soil fertility also. ${ }^{[106]}$ A gene $(o p h B)$ from the bacterial strain pseudomonas sp. BF1-3 was cloned into escherichia coli $D H 5 \alpha$ and it was able to degrade $97 \%$ of $\mathrm{CP}\left(100 \mathrm{mg} \mathrm{L}^{-1}\right)$ and $86 \%$ of TCP in 9 days of incubation. ${ }^{[107]}$

\section{Photocatalytic degradation}

The biodegradation of CP is achieved efficiently with a good percentage, but the process mostly takes a long time for degradation and also it is not a costeffective treatment. The degradation with nanoparticles is an alternative to such traditional methods. Nanoparticles have a very small size between $1-100 \mathrm{~nm},{ }^{[108]}$ which leads to an increase in surface area to volume ratio and favors enhanced degradation. ${ }^{[109]}$ Many studies ${ }^{[7,110-114]}$ explained the consequential role played by metal $\mathrm{NPs}$ like $\mathrm{Fe}, \mathrm{Au}, \mathrm{Ag}, \mathrm{TiO}_{2}, \mathrm{ZnO}$ etc. in the degradation of $\mathrm{CP}$.

The advantage of polyurethane foam and cellulose acetate membrane along with NPs has been reported to achieve expeditious mineralization of CP. A piece of $20 \mathrm{~cm} \times 25 \mathrm{~cm}$ polyurethane foam incorporated with silver NPs achieved complete mineralization of $\mathrm{CP}\left(3 \mathrm{mg} \mathrm{L}^{-1}\right)$ in $180 \mathrm{~min}$. Silver NPs with cellulose acetate membrane achieved complete mineralization of $\mathrm{CP}\left(2 \mathrm{mg} \mathrm{L}^{-1}\right)$ in nearly $120 \mathrm{~min}$ using $500 \mathrm{mg}$ of catalyst. The use of silver and gold NPs may lead to better percentage removal ${ }^{[110]}$. The efficiency of silver NPs for consummate degradation of CP from water has been reported. The degradation efficiency has been found to increase over the surface of activated alumina. ${ }^{[111]}$

99\% of CP had been degraded with iron NPs over chitosan with help of carbodiimide laccase. ${ }^{[112]}$ Iron NPs are convenient for the degradation as far as cost is a matter of concern but, if their aggregation takes place then their efficiency gets reduced. ${ }^{[115]}$

Silica NPs coated with molecularly imprinted polymers had shown potential for the detection and degradation of $\mathrm{CP}$ from the complex matrices. In their study, $25 \mathrm{~nm}$ thick layers coated with the vinyl group over $\mathrm{SiO}_{2} \mathrm{NPs}$ show good binding capacity and provide efficient degradation, but the excess of vinyl groups decreased the binding efficiency. ${ }^{[16]}$

Degradation of organophosphate pesticides with heterogeneous photocatalysts is proposed to be a highly attractive and cost-effective technique. The modification of photocatalysts results in the utilization of visible light as an 
energy source. ${ }^{[117]}$ Photocatalysts like $\mathrm{TiO}_{2}$ and $\mathrm{ZnO}$ have shown great efficiency for the degradation of pesticides. Photocatalysts have a high potential to degrade complex organic substances. The excitation of electrons from the valence band to conduction band leads to the formation of electron-hole pair combinations which in turn generates ${ }^{\circ} \mathrm{OH}$ and $\mathrm{O}_{2}{ }^{-}$radicals. Due to very high oxidizing power these radicals have high potential to degrade pesticide adsorbed on the surface of a photocatalyst to simple organic and inorganic substances.

$\mathrm{ZnO}$ over support of a cellulose acetate membrane have shown higher degradation of $5 \mathrm{ppm} \mathrm{CP}$ in $60 \mathrm{~min}$ under $\mathrm{UV}$ radiations than $\mathrm{ZnO}$ alone. ${ }^{[114]}$ $\mathrm{TiO}_{2}$ had shown a higher tendency to degrade aqueous suspensions of $\mathrm{CP}(10$ $30 \mathrm{mg} \mathrm{L}^{-1}$ ) in sunlight than $\mathrm{ZnO}$ nanoparticles. $\mathrm{TiO}_{2}$ achieved complete degradation within 100 min whereas $\mathrm{ZnO}$ was unable to achieve complete degradation. The study also observed that degradation was enhanced in an acidic medium. ${ }^{[118]}$ Under UV radiations $\mathrm{TiO}_{2}$ had shown nearly $90 \%$ degradation of $\mathrm{CP}$ in 25 min of irradiation whereas only $80 \%$ degradation was achieved with $\mathrm{ZnO}$. The optimum concentration of catalyst $0.15 \mathrm{~g} \mathrm{~L}^{-1}$ and $\mathrm{pH} 9$ were observed. [119]

The presence of $\mathrm{H}_{2} \mathrm{O}_{2}$ had shown a marked effect on the degradation of CP. The results verified that there is an enhancement in the activity of $\mathrm{TiO}_{2}$ under UV light with the presence of $\mathrm{H}_{2} \mathrm{O}_{2}{ }^{[120,121]}$. The effect of various anions and other parameters like temperature, $\mathrm{pH}, \mathrm{H}_{2} \mathrm{O}_{2}$, etc., during the degradation of $\mathrm{CP}$ under $\mathrm{UV}$ radiations, is reported. Temperature and $\mathrm{pH}$ did not show any significant effect on degradation. The addition of $\mathrm{H}_{2} \mathrm{O}_{2}$ provides enhanced degradation under alkaline medium in UV light. The addition of $\mathrm{H}_{2} \mathrm{O}_{2}$ enhanced the degradation and $1.5 \mathrm{~g} \mathrm{~L}^{-1}$ amount of $\mathrm{H}_{2} \mathrm{O}_{2}$ was observed to be optimum, however, the presence of other ions like chloride, nitrate, sulfate, and bicarbonate anions does not show any significant impact on degradation efficiency. ${ }^{[122]}$

It is also reported that an excessive concentration of $\mathrm{H}_{2} \mathrm{O}_{2}$ might decrease the performance because $\mathrm{H}_{2} \mathrm{O}_{2}$ produces water molecules by reacting with hydroxyl radicals that might lead to some other reactions. ${ }^{[123]}$ Murillo et al. ${ }^{[12]}$ reported more than $90 \%$ degradation of $\mathrm{CP}$ in sunlight with a $1 \mathrm{~g} \mathrm{~L}^{-1}$ dose of $\mathrm{TiO}_{2}$. However, better results were obtained when $0.02 \mathrm{M} \mathrm{H}_{2} \mathrm{O}_{2}$ was used in the reaction mixture. Only $10 \mathrm{mg} \mathrm{L}^{-1}$ catalyst dose along with $\mathrm{H}_{2} \mathrm{O}_{2}$ provided better results than alone $1 \mathrm{~g} \mathrm{~L}^{-1}$ catalyst dose. ${ }^{[124]}$

Most of the studies recognized higher degradation of $\mathrm{CP}$ under acidic medium. ${ }^{[124,125]}$ Sivagami et al. ${ }^{[125]}$ also reported $80-90 \%$ degradation of $\mathrm{CP}$ with varying amounts of $\mathrm{TiO}_{2}\left(0.5-2 \mathrm{~g} \mathrm{~L}^{-1}\right)$ and concentration of $\mathrm{CP}\left(5-50 \mathrm{mg} \mathrm{L}^{-1}\right)$ under acidic conditions.

Doping of $\mathrm{TiO}_{2}$ with $\mathrm{V}^{5+}, \mathrm{Mo}^{6+}$, and $\mathrm{Th}^{4+}$ has also shown remarkable degradation potential for $\mathrm{CP}$ under solar light. Among these doped photocatalysts $\mathrm{Th}^{4+}\left(0.06 \% \mathrm{TiO}_{2}\right)$ has shown maximum activity in solar light. But, in UV light undoped $\mathrm{TiO}_{2}$ had shown high activity than doped photocatalyst. ${ }^{[126]}$

Photocatalytic degradation of $\mathrm{CP}$ with $\mathrm{Co}-\mathrm{Fe}$ nanocomposites has been observed to be cheap, eco-friendly and reusable. ${ }^{[127]}$ The low cost of $\mathrm{TiO}_{2}$ makes its utilization convenient at an immensely large scale. ${ }^{[128]}$ The various photocatalysts used for the degradation of $\mathrm{CP}$ and their efficiencies are summarized in Table [d].

Table [d]. Degradation of CP with nanoparticles.

\begin{tabular}{|c|c|c|c|c|c|c|c|c|}
\hline $\begin{array}{l}\text { Sr. } \\
\text { No. }\end{array}$ & Nanoparticle & $\begin{array}{l}\text { Support material/ } \\
\text { Membrane }\end{array}$ & Light Source & $\begin{array}{c}\text { Concentration of } \\
\text { CP }\end{array}$ & Optimal conditions & Comments & $\begin{array}{c}\text { Maximum } \\
\text { degradation } \\
\text { time }\end{array}$ & Reference \\
\hline 1. & Silver NP & Poly Urethane Foam & - & $3 \mathrm{ppm}$ & - & $\begin{array}{l}\text { Complete } \\
\text { removal }\end{array}$ & $180 \mathrm{~min}$ & [7] \\
\hline 2. & Silver NP & Cellulose acetate Membrane & - & $2 \mathrm{mg} \mathrm{L}^{-1}$ & - & $100 \%$ removal & $\begin{array}{c}\text { nearly } 120 \mathrm{~min} \\
\text { with } 500 \mathrm{mg} \mathrm{L}^{-1} \\
\text { Ag NPs }\end{array}$ & {$[110]$} \\
\hline 3. & Silver NP & Alumina & UV & $1 \mathrm{ppm}$ & - & $\begin{array}{c}\text { Complete } \\
\text { removal }\end{array}$ & $10 \mathrm{~h}$ & [111] \\
\hline 4. & Gold NP & Citrate & UV & $2 \mathrm{ppm}$ & - & $\begin{array}{l}\text { Complete } \\
\text { removal }\end{array}$ & $4 \mathrm{~h}$ & [111] \\
\hline 5. & $\begin{array}{l}\text { Magnetic iron } \\
\text { NPs }\end{array}$ & $\begin{array}{l}\begin{array}{l}\text { Laccase immobilization on } \\
\text { chitosan coated NP }\end{array} \\
\end{array}$ & - & $500 \mathrm{mg} \mathrm{L}^{-1}$ & $\mathrm{pH}=7$, temperature $60^{\circ} \mathrm{C}$ & $99 \%$ & $12 \mathrm{~h}$ & [112] \\
\hline 6. & $\mathrm{TiO}_{2}$ & - & UV lamp (16 W) & $2-10 \mathrm{mg} \mathrm{L}^{-1}$ & $\mathrm{pH}=5, \mathrm{TiO}_{2}(100 \mathrm{mg} / 100 \mathrm{~mL})$ & $97.6-98.6 \%$ & $60 \mathrm{~min}$ & {$[113]$} \\
\hline 7. & $\mathrm{ZnO}$ & $\begin{array}{l}\text { Cellulose acetate mixed } \\
\text { polymeric membrane }\end{array}$ & UV lamp (11 W) & $5 \mathrm{mg} \mathrm{L}^{-1}$ & - & - & $60 \mathrm{~min}$ & [114] \\
\hline 8. & $\mathrm{TiO}_{2}$ and $\mathrm{ZnO}$ & - & Sun light & $10-30 \mathrm{mg} \mathrm{L}^{-1}$ & $\begin{array}{c}\mathrm{ZnO}=0.25 \mathrm{~g} \mathrm{~L}^{-1} \\
\mathrm{TiO}_{2}=0.75 \mathrm{~g} \mathrm{~L}^{-1} \\
\mathrm{pH}(\mathrm{ZnO})=6.4 \\
\mathrm{pH}\left(\mathrm{TiO}_{2}\right)=4.2\end{array}$ & $100 \%$ for $\mathrm{TiO}_{2}$ & $120 \mathrm{~min}$ & [118] \\
\hline 9. & $\mathrm{TiO}_{2}$ and $\mathrm{ZnO}$ & - & UV & $6 \mathrm{mg} \mathrm{L}^{-1}$ & $\begin{array}{c}\mathrm{pH}=9 \\
\text { catalyst dose }=0.15 \mathrm{~g} \mathrm{~L}^{-1}\end{array}$ & $\begin{array}{l}80 \% \text { for } \mathrm{ZnO} \\
90 \% \text { for } \mathrm{TiO}_{2}\end{array}$ & $25 \mathrm{~min}$ & [119] \\
\hline 10. & $\mathrm{TiO}_{2}$ & - & $\begin{array}{c}\mathrm{UV}(365 \mathrm{~nm}) / \\
\mathrm{H}_{2} \mathrm{O}_{2}(100 \mathrm{mg} / \mathrm{L})\end{array}$ & $\begin{array}{l}400 \mathrm{mg} \mathrm{L}^{-1}(100 \\
\text { CP, } 50 \\
\text { cypermethrin, } 250 \\
\text { chlorothalonil }) \\
\end{array}$ & $\mathrm{pH}=6, \mathrm{TiO}_{2}=1.5 \mathrm{~g} \mathrm{~L}^{-1}$ & $\begin{array}{l}\text { Complete } \\
\text { removal }\end{array}$ & $\begin{array}{l}30 \mathrm{~min} \text { (total } \\
\text { irradiation time } \\
300 \mathrm{~min} \text { ) }\end{array}$ & {$[120]$} \\
\hline 11. & $\mathrm{TiO}_{2}$ & & $\mathrm{UV} / \mathrm{H}_{2} \mathrm{O}_{2}$ & $50-150 \mathrm{mg} \mathrm{L}^{-1}$ & $\mathrm{H}_{2} \mathrm{O}_{2}=1.5 \mathrm{gL}^{-1}$ & & & {$[122]$} \\
\hline 12. & $\mathrm{TiO}_{2}$ & - & $\begin{array}{l}\text { Sun light / } 0.02 \mathrm{M} \\
\qquad \mathrm{H}_{2} \mathrm{O}_{2}\end{array}$ & $30 \mathrm{mg} \mathrm{L}^{-1}$ & $\mathrm{TiO}_{2}=10 \mathrm{mg} \mathrm{L}^{-1}$ & Nearly $90 \%$ & $20 \mathrm{~min}$ & [124] \\
\hline 13. & $\mathrm{TiO}_{2}$ & - & UV & $5-25 \mathrm{mg} \mathrm{L}^{-1}$ & $\begin{array}{c}\mathrm{pH}<7 \\
\mathrm{TiO}_{2}=1 \mathrm{~g} \mathrm{~L}^{-1}\end{array}$ & $80-90 \%$ & - & [125] \\
\hline 14. & $\begin{array}{l}\mathrm{Co}-\mathrm{Fe}-\mathrm{TiO}_{2} \\
\text { nano composite }\end{array}$ & $\begin{array}{l}\text { Reduced graphene oxide } \\
\text { nanocomposite }\end{array}$ & UV lamp (400 W) & $5 \mathrm{mg} \mathrm{L}^{-1}$ & $\mathrm{pH}=5.8$ & - & $60 \mathrm{~min}$ & [127] \\
\hline 15. & $\mathrm{TiO}_{2}$ & - & UV lamp (9 W) & $5-25 \mathrm{mg} \mathrm{L}^{-1}$ & $\begin{array}{c}\text { no significant effect of } \mathrm{pH} \\
\mathrm{TiO}_{2}=1 \mathrm{~g} \mathrm{~L}^{-1}\end{array}$ & $\begin{array}{c}84-94 \% \\
\text { degradation }\end{array}$ & $4-5 \mathrm{~h}$ & [140] \\
\hline 16. & $\begin{array}{l}\mathrm{Cd}, \mathrm{Te} \\
\text { Quantum Dots }\end{array}$ & Alumina & - & - & - & $\begin{array}{c}\text { Complete } \\
\text { removal }\end{array}$ & - & [145] \\
\hline 17. & $\mathrm{TiO}_{2}$ & - & $\mathrm{UV}\left(27-30 \mathrm{~W} \mathrm{~m}^{-2}\right)$ & $2 \mathrm{mg} \mathrm{L}^{-1}$ & $\begin{array}{c}\mathrm{pH}=6.5 \\
\mathrm{TiO}_{2}=4 \mathrm{~g} \mathrm{~L}^{-1}\end{array}$ & $94 \%$ & $8 \mathrm{hrs}$ & [149] \\
\hline
\end{tabular}




\section{Other methods used for degradation of CP}

Besides biodegradation and photocatalytic degradation, other efficacious methods such as electrochemical, hydrolytic, ultrasonic methods, etc. have been developed for the degradation of $\mathrm{CP}$, which shows good efficacy for degradation of CP. Liu et al. ${ }^{[129]}$ observed the hydrolytic degradation of CP from various river water of the Chesapeake Bay region gives TCP as a major product. The \%age recovery of CP and TCP varies from 103-116\%. The study also shows that along with $\mathrm{pH}$, the presence of dissolved metals like copper additionally affects the degradation process.

The enzymatic hydrolysis of $\mathrm{CP}$ had been prosperously achieved by paraoxonase. Hydrolysis was quick in the presence of chloride ions, however, the presence of EDTA, phenylacetate inhibited the hydrolysis. The solvent also has a consequential effect as the hydrolysis was found to be enhanced in the presence of methanol instead of acetone. ${ }^{[130]}$

Electrochemical methods had also been effective for the purpose. ${ }^{[131,132]}$ The mineralization of $\mathrm{CP}$ with graphite carbon as the cathode and $\mathrm{Nb} / \mathrm{PbO}_{2}$ as anode showed more than 70\% COD removal at an ambient temperature of $60^{\circ} \mathrm{C}$ and with a current density of $50 \mathrm{~mA} \mathrm{~cm}{ }^{-2}$ within $10 \mathrm{hrs}$. The utilization of borondoped diamond as anode had led to proximately $99 \%$ COD removal with relatively lower current density $\left(20 \mathrm{~mA} \mathrm{~cm}{ }^{-2}\right)$ within $6 \mathrm{hrs}$ only. So, the use of the boron-doped diamond had shown better efficiency for the mineralization of CP.

The ultrasonic irradiation reported the formation of two metabolites TCP and $\mathrm{CPO}$ during degradation. The parameters like $\mathrm{pH}$, temperature and electric power were also monitored and degradation was found to vary with variations of the parameters. The maximum degradation $(85 \%)$ was observed at $\mathrm{pH} 7$ at electric power $900 \mathrm{~W}$ and $25^{\circ} \mathrm{C}$ temperature. ${ }^{[133]}$ The degradation of $\mathrm{CP}$ increases with an increase in electric power and ultrasound frequency. However, no significant effect with variation in $\mathrm{pH}$ was observed. ${ }^{[134]}$

Low doses of oxytetracyclene (OTC) enhance the mineralization of CP. ${ }^{[135]}$ The degradation of $\mathrm{CP}$ in pure water and sludge utilizing activated carbon and micelle clay complexes demonstrated that ultra filtration-hollow fiber column was unable to abstract $\mathrm{CP}$, but the mixing of activated carbon or micelle clay complexes filtration resulted in the efficient removal of CP. Experimental results showed that the use of octadecyltrimethylammonium bromide (ODTMA) complexes degraded CP up to $90 \%$ in 180 min of contact time. ${ }^{[8]}$

Treatment with microencapsulated $\mathrm{CP}$ in the soil gives virtually complete abstraction of $\mathrm{CP}$ with an initial concentration of 5 and $20 \mathrm{mg} \mathrm{kg}^{-1}$. However, this dissipation was observed to be slower than emulsifiable $\mathrm{CP}$ treated soil, but side effects on soil microbes were less than emulsifiable CP. ${ }^{[64]}$ The plant elodea densa had the competency to absorb the $\mathrm{CP}$ from water. The experiments reported that plant material elodea densa could adsorb $\mathrm{CP}$ in a fortnight to dissipate CP. ${ }^{[136]}$

Utilizing oxidizing agents like hydrogen peroxide, potassium permanganate, etc. in high concentration for removal of pesticides from nectarines led to the formation of $\mathrm{CPO}$ that is more toxic than its parent compound. The formation of toxic by-products was confirmed by Gas Chromatography-Mass spectroscopy (GC-MS) technique, however, the use of simple washing technique with the addition of ethanol, glycerol, and sodium lauryl sulphate (SLS) was found to be efficacious for removal of CP. ${ }^{[137]}$

Gamma radiations had shown the potential to degrade aqueous solutions of low concentration of $\mathrm{CP}\left(5 \mathrm{mg} \mathrm{L}^{-1}\right)$. In the presence of sunlight $\mathrm{CP}\left(20 \mathrm{mg} \mathrm{L}^{-1}\right)$ is degraded up to $33.5 \%$ and $47.15 \%$ after 10 days. ${ }^{[138]}$ Such common methods studied for the degradation of $\mathrm{CP}$ are summarized in Table [e].

Table [e]. Other methods used for degradation of CP.

\begin{tabular}{|c|c|c|c|c|c|c|}
\hline $\begin{array}{l}\text { Sr. } \\
\text { No. }\end{array}$ & Method & Surface / Light source & Concentration of $\mathbf{C P}$ & Degradation \%age & Optimal conditions/ factors & Reference \\
\hline 1 & $\begin{array}{l}\text { Micelle clay complex and } \\
\text { advanced treatment } \\
\text { technology }\end{array}$ & $\begin{array}{l}\text { Activated carbon / } \\
\text { micelle clay complex } \\
\text { (ODTMA) }\end{array}$ & $100 \mathrm{mg} / \mathrm{L}$ & $90 \%$ & $\begin{array}{l}\text { Total contact time } 180 \mathrm{~min}, \\
\text { optimal contact time } 30 \pm 5 \mathrm{~min} \text {, } \\
\text { pH } 6.58 \text { and temperature } 25^{\circ} \mathrm{C}\end{array}$ & {$[8]$} \\
\hline 2 & Atmospheric degradation & Solar radiations & $\begin{array}{c}\text { Injection with pressure } \\
2 * 10^{5} \mathrm{~mm} \mathrm{Hg}\end{array}$ & $95 \%$ degradation & $\begin{array}{l}\text { Presence of }\left[\mathrm{NO}_{\mathrm{x}}\right],\left[\mathrm{OH}^{0}\right] \\
\text { enhance degradation }\end{array}$ & {$[30]$} \\
\hline 3 & Microencapsulated CP & - & 5 and $20 \mathrm{mg} \mathrm{CP} \mathrm{kg}^{-1}$ & - & $\begin{array}{l}\text { Disappearance of CP after } 120 \\
\mathrm{~d}\end{array}$ & {$[64]$} \\
\hline 4 & Hydrolytic degradation & - & $20 \mu \mathrm{g} \mathrm{L}^{-1}$ & - & $\begin{array}{l}\mathrm{pH} \text {, dissolved metals show } \\
\text { significant effect }\end{array}$ & [129] \\
\hline 5 & Hydrolytic degradation & $\begin{array}{l}\text { Human serum plasma } \\
\text { paraoxonase / } \\
\text { arylesterase }\end{array}$ & - & - & Presence of chloride ions & {$[130]$} \\
\hline \multirow[t]{2}{*}{6} & \multirow[t]{2}{*}{ Electrochemical } & Anode, $\mathrm{Nb} / \mathrm{PbO}_{2}$ & \multirow[t]{2}{*}{$\mathrm{COD}=115-450 \mathrm{mg} \mathrm{L}^{-1}$} & \multirow[t]{2}{*}{ COD removal $76 \%$} & \multirow{2}{*}{$\begin{array}{l}\text { Current density } 50 \mathrm{~mA} \mathrm{~cm}^{-2} \text {, } \\
\text { temperature } 70^{\circ} \mathrm{C} \text {, time } 10 \mathrm{~h}\end{array}$} & \multirow[t]{2}{*}[131]{} \\
\hline & & $\begin{array}{l}\text { Cathode, graphite } \\
\text { carbon }\end{array}$ & & & & \\
\hline \multirow[t]{2}{*}{7} & \multirow[t]{2}{*}{ Electrochemical } & $\begin{array}{l}\text { Anode, boron doped } \\
\text { diamond }\end{array}$ & \multirow[t]{2}{*}{ COD, 115- $450 \mathrm{mg} \mathrm{L}^{-1}$} & \multirow[t]{2}{*}{$\begin{array}{c}\text { COD removal }>99 \\
\%\end{array}$} & \multirow{2}{*}{$\begin{array}{l}\text { Current density } 20 \mathrm{~mA} \mathrm{~cm}^{-2} \\
\text { and temperature } 70^{\circ} \mathrm{C} \text {, time } 6 \mathrm{~h} \text {, } \\
\mathrm{pH}=2\end{array}$} & \multirow[t]{2}{*}[132]{} \\
\hline & & $\begin{array}{l}\text { Cathode, graphite } \\
\text { carbon }\end{array}$ & & & & \\
\hline \multirow[t]{2}{*}{8} & \multirow[t]{2}{*}{ Ultrasonic irradiations } & Electric Power & \multirow[t]{2}{*}{$1.4 \mathrm{mg} \mathrm{L}^{-1}$} & \multirow[t]{2}{*}{$85 \%$ mineralization } & \multirow{2}{*}{$\begin{array}{l}\text { Temperature } 25^{\circ} \mathrm{C}, \mathrm{pH}=7, \\
\text { electric power } 900 \mathrm{~W} \text {, time } 60 \\
\text { min }\end{array}$} & \multirow[t]{2}{*}[133]{} \\
\hline & & $900 \mathrm{~W}$ & & & & \\
\hline \multirow[t]{2}{*}{9} & \multirow[t]{2}{*}{ Ultrasound } & Electric power & \multirow[t]{2}{*}{$1 \mathrm{mg} \mathrm{L}^{-1}$} & \multirow[t]{2}{*}{$98.96 \%$} & \multirow{2}{*}{$\begin{array}{l}\mathrm{pH}=9, \text { frequency } 130 \mathrm{kHz}, \\
\text { contact time } 20 \mathrm{~min} \text {, electric } \\
\text { power } 500 \mathrm{~W}\end{array}$} & \multirow[t]{2}{*}{ [134] } \\
\hline & & $500 \mathrm{~W}$ & & & & \\
\hline 10 & Effect of OTC on biomixture & - & $50 \mathrm{mg} \mathrm{kg}^{-1}$ & - & $\begin{array}{l}\text { Low doses of OTC }(1-10 \mathrm{mg} \\
\left.\mathrm{kg}^{-1}\right) \text { increased mineralization } \\
\text { of CP }\end{array}$ & {$[135]$} \\
\hline 11 & Aquatic Macrophyte & Elodea densa & - & - & $\begin{array}{l}\text { Tendency to accumulate CP } \\
\text { from water in } 2 \text { weeks }\end{array}$ & [136] \\
\hline 12 & Washing process & SLS, Ethanol & - & $50 \%$ & $\begin{array}{l}\text { Hydrophobic nature of SLS } \\
\text { makes it effective }\end{array}$ & [139] \\
\hline
\end{tabular}

The analysis of intermediates formed during the degradation of $\mathrm{CP}$ is necessary to confirm the toxicity of degraded products. The formation of intermediates under biodegradation, photocatalytic degradation, etc., and the residual concentration of CP are traced with techniques [113,120,139,140] like UV spectroscopy, GC, Liquid Chromatography-Mass Spectroscopy (LC-MS), and High Performance Liquid Chromatography (HPLC). 
The quantitative determination of $\mathrm{CP}$ along with dimethoate, fenthion, diazinon simultaneously in human blood has been prosperously achieved. ${ }^{[141]}$ Some common and efficient techniques used so far for analysis of such degraded products are listed in Table [f].

Table [f]. Techniques used for analysis of CP and its degraded products

\begin{tabular}{|c|c|c|c|}
\hline $\begin{array}{l}\text { Sr. } \\
\text { No. }\end{array}$ & $\begin{array}{l}\text { Technique for analysis of CP/ } \\
\text { degraded products of } \mathrm{CP}\end{array}$ & $\begin{array}{c}\text { Degradation } \\
\text { method }\end{array}$ & Reference \\
\hline 1 & $\begin{array}{l}\text { HPLC, Quantitative determination } \\
\text { of CP/TCP }\end{array}$ & Biodegradation & [81] \\
\hline 2 & $\begin{array}{l}\text { GC-Flame Ionization Detector, } \\
\text { Degradation of CP/TCP }\end{array}$ & Biodegradation & {$[82]$} \\
\hline 3 & TCP analysis, HPLC & Biodegradation & {$[88]$} \\
\hline 4 & GC-MS & Photocatalytic & [112] \\
\hline 5 & UV spectroscopy & Photocatalytic & [113] \\
\hline 6 & GC-MS & Photocatalytic & {$[120]$} \\
\hline 7 & LC-MS & Photocatalytic & {$[127]$} \\
\hline 8 & GC-MS analysis & Ultrasonic & [133] \\
\hline 9 & $\begin{array}{l}\text { TCP analysis, HPLC and UV } \\
\text { spectrometry }\end{array}$ & Photocatalyst & [139] \\
\hline 10 & $\begin{array}{l}\text { Liquid chromatography-tandem } \\
\text { mass spectrometry }\end{array}$ & -- & {$[141]$} \\
\hline 11 & GC-Nitrogen Phosphorus Detector & -- & [146] \\
\hline 12 & LC-MS & -- & [147] \\
\hline 13 & $\begin{array}{l}\text { Liquid-Liquid extraction and } \\
\text { subsequent normal phase solid- } \\
\text { phase extraction }\end{array}$ & -- & [148] \\
\hline
\end{tabular}

\section{General Pathway of Degradation}

To the best of our knowledge, this is the first review that deals exclusively with the degradation of $\mathrm{CP}$. The degradation of $\mathrm{CP}$ with natural methods, biodegradation, and photocatalytic systems have been reviewed above. The results obtained by various techniques like HPLC, ${ }^{[87,139]}$ GC-MS have shown the formation of two major intermediates TCP and DEP during the degradation of CP.

However, the degradation of $\mathrm{CP}$ occurs through the formation of $\mathrm{CPO}$ in which $\mathrm{P}=\mathrm{S}$ moiety of $\mathrm{CP}$ is replaced by $\mathrm{P}=\mathrm{O}$ in presence of some oxidizing agents like $\mathrm{H}_{2} \mathrm{O}_{2}$. ${ }^{[137]}$ The studies show the formation of CPO before TCP and DEP, however, at the cessation of the process, no traces of these intermediates are observed as they can be degraded into simpler inorganic ions. Most of the studies provide evidence that the pyridine ring of $\mathrm{CP}$ remains intact during the degradation. The $\mathrm{CP}$ is found to form multi-oxygenated products under atmospheric conditions. Biodegradation of $\mathrm{CP}$ may provide the precursors of the Krebs cycle. The formation of TCP in almost all pathways indicates the retention of the pyridine ring. TCP is a major metabolite of $\mathrm{CP}$ and under all photolytic and photocatalytic pathways, it is observed to undergo ring cleavage to form smaller organic and inorganic molecules. The products formed during various degradation methods are shown in Figure 4.

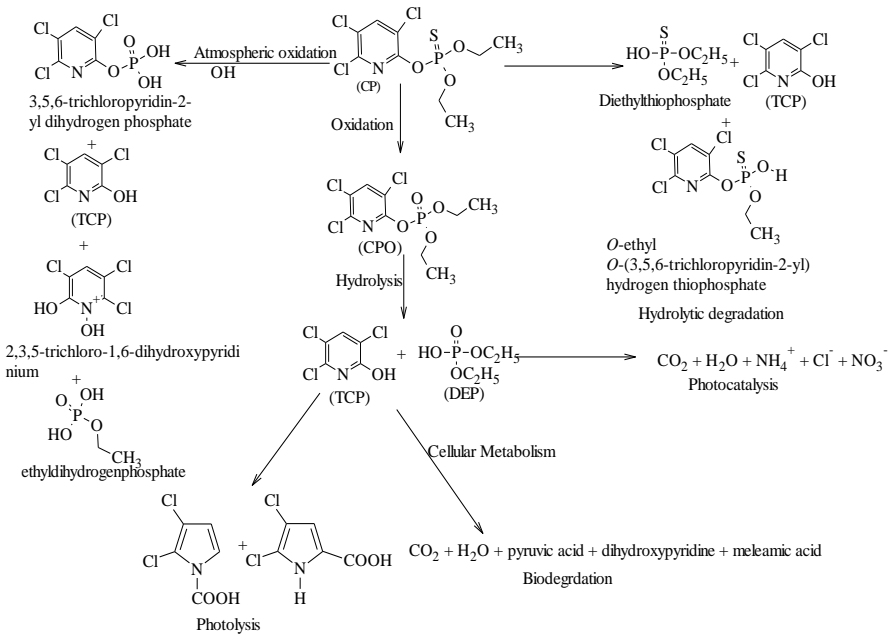

Figure 4. General pathway for degradation of $\mathrm{CP}$ with different methods.

\section{CONCLUSION}

The studies on chlorpyrifos recognize the toxic effects on various living organisms including humans. The inhalation of chlorpyrifos above the maximum residue limit causes neurotoxicity and even death in some cases. Therefore, its degradation is necessary for the safety of organisms and the environment. For this purpose, studies are reviewed in this paper and it is concluded that the various degradation methods like natural degradation, biodegradation, photocatalytic degradation, electrochemical degradation etc. have their own advantages and disadvantages. However, biodegradation is a promising technique for complete mineralization, but it takes a long time for treatment. Moreover, for the biological degradation, it is important to know molecular characterization and genome sequence of insecticide-degrading micro-organisms to better understand the mechanism of insecticide degradation at the gene level so that plant growthpromoting microbes can be developed which can act even under insecticide stress. This will help in designing new alternative and efficient tools for the bioremediation of contaminated sites. Photocatalytic degradation has also shown great efficiency for the insecticide-degradation but the future will be towards the practical applicability and develop the commercial designs. Another future approach is to investigate the effectiveness of hybrid technologies in combination with other existing technologies for the treatment of insecticides like $\mathrm{CP}$ contaminated wastewater. Indeed, the combination of such methods for e.g., the combination of photocatalytic degradation and biodegradation by understanding the mechanism of both the processes may give better results.

Table [g]. List of Abbreviations.

\begin{tabular}{|l|l|}
\hline Abbreviation Title & Abbreviation Name \\
\hline AcHE & Acetylcholinesterase \\
\hline CP & Chlorpyrifos \\
\hline CPO & Chlorpyrifos oxon \\
\hline DNA & 2-deoxyribosenucleic acid \\
\hline DEP & Diethylphosphate \\
\hline GC-MS & Gas Chromatography-Mass Spectroscopy \\
\hline HPLC & High Performance Mass Spectroscopy \\
\hline LC-MS & Liquid Chromatography-Mass Spectroscopy \\
\hline NPs & Nanoparticles \\
\hline NADPH & Nicotinamide Adenine Dinucleotide Phosphate \\
\hline ODTMA & Octadecyltrimethylammonium bromide \\
\hline OP & Organophosphate \\
\hline OTC & Oxytetracyclene \\
\hline PGPM & Plant Growth Promoting Microbes \\
\hline RNA & Ribose nucleic acid \\
\hline SLS & Sodium Lauryl Sulphate \\
\hline TCP & 3,5,6-trichloropyridinol \\
\hline
\end{tabular}

\section{REFERENCES}

1. Y. Bai, L. Zhou, J. Wang, China. Food Chem. 98, 240-242, (2006)

2. L.G. Costa, G. Giordano, M. Guizzetti, A. Vitalone, Front. Biosci. 13, 12401249, (2008)

3. J.R.P. Cabral, IARC World Health Organization, (1987)

4. T. Galloway, R. Handy. Ecotoxicol. 12, 345-363, (2003)

5. R.W. Bretveld, C.M. Thomas, P.T. Scheepers, G.A. Zielhuis, N. Roeleveld, Reprod. Biol. Endocrin. 4, 30, (2006)

6. G. Bapat, C. Labade, A. Chaudhari, S. Zinjarde, Adv. Colloid Interface Sci. 237, 1-14, (2016)

7. G. Manimegalai, S. Shanthakumar, C. Sharma, Int. J. Sci. Res. 1, 91-94, (2012)

8. M. Qurie, M. Khamis, I. Ayyad, L. Scrano, F. Lelario, S.A. Bufo, G Meccan, R. Karaman, Desalin. Water Treat. 57, 15687-15696, (2015)

9. WHO, IARC. 112, 1-2, (2015)

10. R.R.M. Thengodkar, S. Sivakami, Biodegradation. 21, 637-644, (2010)

11. K.D. Racke, Environmental fate of chlorpyrifos. Rev. Environ. Contam. T. 131, 1-150, (1993)

12. P.H. Howard, Lewis Publishers, 5-13, (1991)

13. L.W. Getzin, J. Econ. Entomol. 74, 158-162, (1981) 
14. X. Chu, H. Fang, X. Pan, X. Wang, M. Shan, B. Feng, Y. Yu, J. Environ. Sci. 20, 464-469, (2008)

15. H. Fang, X. Chu, Y. Yu, X. Wang, X. Yang, J. Yu, J. Environ. Sci. 21, $380-$ 386, (2009)

16. B.K. Singh, A.Walker, D.J. Wright, Bull. Environ. Contam. Toxicol. 69, 181-188, (2002)

17. B.K. Singh, A. Walker, FEMS Microbiol. Rev. 30, 428-471, (2006)

18. D.C.M.P.H Smegal, USEPA. (2000)

19. J. Yen, S. Donerly, E.D. Levin, E.A. Linney, Neurotoxicol. Teratol. 33, 735741, (2011)

20. S.M. Dyer, M. Cattani, D.L. Pisaniello, F.M. Williams, J.W. Edwards, Toxicology. 169, 177-185, (2001)

21. T.B. Gaines, Toxicol. Appl. Pharmacol. 14, 515-534, (1969)

22. A.M. Fan, R.J. Jackson, Regul. Toxicol. Pharmacol. 9, 158-174, (1989)

23. J. Aislabie, G.L. Jones, Aust. J. Soil. Res. 33, 925-942, (1995)

24. Z. Chishti, S. Hussain, K.R. Arshad, A. Khalid, M. Arshad, J. Environ. Manage. 114, 372-380, (2013)

25. A. Alvarez, J.M. Saez, J.S.D. Costa, V.C. Colin, M.S. Fuentes, S.A. Cuozzo, C.S. Benimeli, M.A. Polti, M.J. Amoroso, Chemosphere. 166, 41-62, (2017)

26. B. Kumari, D.P. Singh, Ecol. Eng. 97, 98-105, (2016)

27. H.D. Burrows, M. Canle, J.A. Santaballa, S. Steenken, J. Photoch. Photobio B. 67, 71-108, (2002)

28. S. Devipriya, S. Yesodharan, Sol. Energ. Mat. Sol. C. 86, 309-348, (2005)

29. X. Zhao, H. Cui, Y. Wang, C. Sun, B. Cui, Z. Zeng, J. Agr. Food Chem. 66, 6504-6512, (2018)

30. E. Borras, M. Rodenas, M. Vazquez, T. Vera, A. Munoz, Atmos. Environ. 123, 112-120, (2015)

31. M.B. Colovic, D.Z. Krstic, G.S. Uscumlic, V.M. Vasic, Pestic. Biochem Phys. 100, 16-22, (2011)

32. C.G. Canela, E. Prats, B. Pina, R. Taule, Environ. Pollut. 220, 1231-1243, (2017)

33. S.B. Mccollister, R.J. Kociba, C.G. Humiston, D.D. Mccollister, P.J Gehring, Food Cosmet. Toxicol. 12, 45-61, (1974)

34. V. Drevenkar, Z. Vasili, B. Stengl, Z. Frobe, V. Rumenjak, Chem. Biol Interact. 87, 315-322, (1993)

35. R.J. Nolan, D.L. Rick, N.L. Freshour, J.H. Saunders, Appl. Pharmacol. 73, 8-15, (1984)

36. G. Amitai, D. Moorad, R. Adani, B.P. Doctor, Biochem. Pharmacol. 56, 293-299, (1998)

37. B. Xuereb, P. Noury, V. Felten, J. Garric, O. Geffard, Toxicology. 236, 178 $189,(2007)$

38. Y. Jin, Z. Liu, T. Peng, Z. Fu, Fish Shellfish Immunol. 43, 405-414, (2015)

39. G. Giordano, Z. Afsharinejad, M. Guizzetti, A. Vitalone, T.J. Kavanagh, L.G. Costa, Toxicol. Appl. Pharmacol. 219, 181-189, (2007)

40. Z. Zhang, Q. Liu, J. Cai, J. Yang, Q. Shen, S. Xu, Fish Shellfish Immunol. 67, 604-611, (2017)

41. A. Marchand, J.M. Porcher, C. Turies, E. Chadili, O. Palluel, P. Baudoin, S. Betoulle, A.B. Nilles, Ecotoxicol. Environ. Saf. 145, 333-339, (2017)

42. F. Khalil, X. Qiu, I.J. Kang, I.A. Ghanema, Y. Shimasaki, Y. Oshima, Ecotoxicol. Environ. Saf. 145, 78-82, (2017)

43. D.E. Johnson, F.J. Seidler, T.A. Slotkin, Brain Res. Bull. 45, 143-147, (1998)

44. V.C. Moser, S. Padilla, Toxicol. Appl. Pharmacol. 149, 107-119, (1998)

45. C.N. Pope, T.K. Chakraborti, Toxicology. 73, 35-43, (1992)

46. C.N. Pope, T.K. Chakraborti, M.L. Chapman, J.D. Farrar, D. Arthun, Toxicology., 68, 51-61, (1991)

47. J. Gao, S.X. Naughton, W.D. Beck, C.M. Hernandez, G. Wu, Z. Wei, X. Yang, M.G. Bartlett, A.V.T. Jr, Neurotoxicology. 62, 111-123, (2017)

48. J.G. Silva, A.C. Boareto, A.K. Schreiber, D.D.B. Redivo, E. Gambeta, F. Vergara, H. Morais, J.M. Zanoveli, P.R. Dalsenter, Neurosci. Lett. 641, 94 100, (2017)

49. A. Smida, S. Ncibi, J. Taleb, A.B. Saad, S. Ncib, L. Zourgui, Biomed. Pharmacother. 88, 844-851, (2017)

50. H.G. Kang, S.H. Jeong, J.H. Cho, D.G. Kim, J.M. Park, M.H. Cho, Toxicology. 199, 219-230, (2004)

51. L.G. Costa, B.E. Mcdonald, S.D. Murphy, G.S. Omenn, R.J. Richter, A. Motulsky, C.E. Purlong, Toxicol. Appl. Pharmacol. 103, 66-76, (1990)

52. T.A. Slotkin, F.J. Seidler, Dev. Brain Res. 158, 115-119, (2005)

53. G.A. Dominah, R.A. Mcminimy, S. Kallon, G.F. Kwakye, Neurotoxicology. 60, 54-69, (2017)

54. P. Dubey, A.K. Mishra, P. Shukla, A.K. Singh, Pestic. Biochem. Physiol. 124, 29-36, (2015)

55. C. Fernandes, E. Figueira, R. Tauler, C. Bedia, Ecotoxicol. Environ. Saf. 156, 25-33, (2018)
56. D. Qiao, F.J. Seidler, T.A. Slotkin, Toxicol. Appl. Pharmacol. 206, 17-26, (2005)

57. S. Karanth, C. Pope, Toxicol. Sci. 58, 282-289, (2000)

58. T.A. Slotkin, F.J. Seidler, Toxicol. Appl. Pharmacol. 233, 211-219, (2008)

59. X. Zhang, Y. Shen, X.Y. Yu, X.J. Liu, Ecotoxicol. Environ. Saf. 78, 276280, (2012)

60. R.R. Jameson, F.J. Seidler, T.A. Slotkin, Environ. Health Perspect. 115, 65 70, (2007)

61. V. Asselborn, C. Fernandez, Y. Zalocar, E.R. Parodi, Ecotoxicol. Environ Saf. 120, 334-341, (2015)

62. J.C.S. Hernandez, M. Sandoval, Ecotoxicol. Environ. Saf. 142, 303-311, (2017)

63. J.C.S. Hernandez, M. Sandoval, A. Pierart, Ecol. Indic. 73, 525-535, (2017)

64. L. Chen, Y. Li, T. Wang, Y. Jiang, K. Li, Y. Yu, J. Environ. Sci. 26, 2322 2330, (2014)

65. T. Jager, T. Crommentuijn, C.A.M. Gestel, S.A.L.M. Kooijman, Environ Pollt. 145, 452-458, (2007)

66. J.P. Verma, D.K. Jaiswal, R. Sagar, Rev. Environ. Sci. Biotechnol. 13, 429 466, (2014)

67. H. Khan, A. Zeb, Z. Ali, S.M. Shah, Soil Environ. 28, 56-59, (2009)

68. D.W. Sparling, G. Fellers, Environ. Pollt. 147, 535-539, (2007)

69. B. Marouane, S.E. Hajjaji, A.E. Yadini, A. Dahchour, Bas. Res. J. Agric. Sc. and Rev. 4, 239-245, (2015)

70. T.A. Slotkin, F.J. Seidler, C. Wu, E.A. MacKillop, K.G. Linden, Environ Health Perspect. 117, 338-343, (2009)

71. M.I. Pinto, R. Salgado, B.A. Cottrell, W.J. Cooper, H.D. Burrows, C. Vale, G. Sontag, J.P. Noronha, J. Photochem. Photobiol. A Chem. 310, 189-196, (2015)

72. D. Barcelo, G. Durand, N.D. Bertrand, Toxicol. Environ. Chem., 38, 183 199, (1993)

73. A. Munoz, M. Rodenas, E. Borras, M. Vazquez, T. Vera, Chemosphere. 111, 522-528, (2014)

74. R.A. Gilani, M. Rafique, A. Rehman, M.F.H. Munis, S.U. Rehman, H.J. Chaudhary, J. Basic Microbiol. 56, 105-119, (2016)

75. M. Yadav, N. Srivastva, R.S. Singh, S.N. Upadhyay, S.K. Dubey, Bioresour Technol. 165, 265-269, (2014)

76. J. Liu, L. Tan, J. Wang, Z. Wang, H. Ni, L. Li, Chemosphere. 157, 200-207, (2016)

77. K. Maya, R.S. Singh, S.N. Upadhyay, S.K. Dubey, Process Biochem. 46 2130-2136, (2011)

78. A.E.S.A. Ishag, A.O. Abdelbagi, A.M.A. Hammad, E.A. Elsheikh, O.E. Elsaid, J.H. Hur, M.D. Laing, J. Agr. Food Chem. 64, 8491-8498, (2016)

79. E.R.E. Helow, M.E.I. Badawy, M.E.M. Mabrouk, E.A.H. Mohamed Y.M.E. Beshlawy, Bioremediat. J. 17, 113-123, (2013)

80. K. Duraisamy, S. Muthusamy, S. Balakrishnan, Biocatal. Agric. Biotechnol. 13, 283-290, (2018)

81. S. Anwar, F. Liaquat, Q.M. Khan, Z.M. Khalid, S. Iqbal, J. Hazard. Mater. $168,400-405,(2009)$

82. L. Yang, Y. Zhao, B. Zhang, C. Yang, X. Zhang, FEMS Microbiol. Lett 251, 67-73, (2005)

83. F. Ahmad, S. Iqbal, S. Anwar, M. Afzal, E. Islam, T. Mustafa, Q.M. Khan, J. Hazard. Mater. 237, 110-115, (2012)

84. C.V. Lakshmi, M. Kumar, S. Khanna, Int. Biodeterior. Biodegradation. 62, 204-209, (2008)

85. G. Kulshrestha, A. Kumari, Biol. Fertil. Soils. 47, 219-225, (2011)

86. B.K. Singh, A. Walker, J.A.W. Morgan, D.J. Wright, Appl. Environ. Microbiol. 70, 4855-4863, (2004)

87. G. Xu, W. Zheng, Y. Li, S. Wang, J. Zhang, Y. Yan, Int. Biodeterior. Biodegradation. 62, 51-56, (2008)

88. G. Briceno, M.S. Fuentes, G. Palma, M.A. Jorquera, M.J. Amoroso, M.C. Diez, Int. Biodeterior. Biodegradation. 73, 1-7, (2012)

89. P. Lu, Q. Li, H. Liu, Z. Feng, X. Yan, Q. Hong, S. Li, Bioresour. Technol. 127, 337-342, (2013)

90. S. Deng, Y. Chen, D. Wang, T. Shi, X. Wu, X. Ma, X. Li, R. Hua, X. Tang, Q.X. Li, J. Hazard. Mater. 297, 17-24, (2015)

91. X. Tang, Y. Yang, R. Tao, P. Chen, Y. Dai, C. Jin, X. Feng, Sci. Total Environ. 571, 935-942, (2016)

92. X. Tang, Y. Yang, W. Huang, M.B. Mcbride, J. Guo, R. Tao, Y. Dai, Bioresour. Technol. 233, 264-270, (2017)

93. Y. Gao, S. Chen, M. Hu, Q. Hu, J. Luo, Y. Li, PLoS One. 7, 1-8, (2012)

94. X. Li, J. He, S. Li, Res. Microbiol. 158, 143-149, (2007)

95. B. Liang, C. Yang, M. Gong, Y. Zhao, J. Zhang, C. Zhu, J. Jiang, S. Li, 92, 2229-2234, (2011)

96. M.E. Parolo, M.C. Savini, R.M. Loewy, J. Environ. Manage. 196, 316-322, (2017) 
97. H. Jabeen, S. Iqbal, S. Anwar, Water and Environ. J. 29, 1-10, (2014)

98. J. Abraham, S. Silambarasan, Process Biochem. 48, 1559-1564, (2013)

99. J. Abraham, S. Silambarasan, Pestic. Biochem. Physiol. 126, 13-21, (2016)

100. S. Akbar, S. Sultan, Braz. J. Microbiol. 47, 563-570, (2016)

101. R. Yang, G. Ji, Q. Zhoe, C. Yaun, J. Shi, Environ. Int. 31, 799-804, (2005)

102. B. Engelen, K. Meinken, F.V. Wintzingerode, H. Heuer, H.P. Malkomes,

H. Backhaus, Appl. Environ. Microbiol. 64, 2814-2821, (1998)

103. N. Mishra, S.K. Sundari, J. Bioprocess. Biotech. 5, 202, (2015)

104. Y. Pratibha, S.S. Krishna, J. Environ. Res. Develop. 9, 1138, (2015)

105. J.P. Verma, D.K. Jaiswal, P.K. Maurya, Energy Ecol. Environ. 1, 408-418, (2016)

106. D.K. Jaiswal, J.P. Verma, R. Krishna, A.K. Gaurav, J. Yadav, Chemosphere. 223, 636-650, (2019)

107. N.D. Barman, M.A. Haque, S. Islam, H.D. Yun, M.K. Kim, Ecotoxicol. Environ. Saf. 108, 135-141, (2014)

108. K.M.M.A. Elnour, A. Eftaiha, A.A. Warthan, R.A.A. Ammar, Arab. J. Chem. 3, 135-140, (2010)

109. S. Gurunathan, K. Kalishwaralal, R. Vaidyanathan, V. Deepak, J. Pandian, S.R.K. Muniyandi, N. Hariharan, S.H. Eom, Colloids Surf. B Biointerfaces. 74, 328-335, (2009)

110. G. Manimegalai, S. Shanthakumar, C. Sharma, Int. nano. Lett. 4, 105, (2014)

111. A.S. Nair, T. Pradeep, J. Nanosci. Nanotechol. 7, 1-7, (2007)

112. A. Das, J. Singh, K.N. Yogalakshmi, Int. Biodeterior. Biodegradation. 117, 183-189, (2017)

113. A. Amalraj, A. Pius, J. Water Process Eng. 7, 94-101, (2015)

114. S.H. Khan, R. Suriyaprabha, B. Pathak, M.H. Fulekar, Front. Nanosci. Nanotechnol. 1, 23-27, (2015)

115. W. Zhang, D.W. Elliott, Remed. J. 16, 7-21, (2006)

116. Q. Lu, X. Chen, L. Nie, J. Luo, H. Jiang, L. Chen, Q. Hu, S. Du, Z. Zhang, Talanta. 81, 959-966, (2010)

117. D. Sud, P. Kaur, A Review. Crit. Rev. Env. Sci. Tec. 42, 2365-2407, (2012)

118. V.G.G. Kanmoni, S. Daniel, G.A.G. Raj, React. kinet. Mech. Cat. 106, 325339, (2012)

119. A. Fadaei, M. Kargar, Fresenius Environ. Bull. 22, 2442-2447, (2013)

120. A.C. Affam, M. Chaudhuri, J. Environ. Manage. 130, 160-165, (2013)

121. N. Miguel, M.P. Ormad, R. Mosteo, J. Ovelleiro, Int. J. Photoenergy. 2012, 1-11, (2012)

122. A.G.D. Oliveira, J.P. Ribeiro, J.T. Oliveira, D.D. Keukeleire, M.S. Duarte, R.F. Nascimento, J. Adv. Oxd. Technol. 1, 133-138, (2014)

123. W.H. Koppenol, J. Butler, J.W. Leeuwen, Photochem. Photobiol. 28, 655658, (1978)

124. R. Murillo, J. Sarasa, M. Lanao, J.L. Ovelleiro, Water Sci. Tech-W Sup. 10, $1-6,(2010)$
125. K. Sivagami, R.R. Krishna, T. Swaminathan, J. Water Sustain. 3, 143-151, (2013)

126. L.G. Devi, B.N. Murthy, S.G. Kumar, J. Mol. Catal. A-Chem. 308, 174181, (2009)

127. V.K. Gupta, T. Eren, N. Atar, M.L. Yola, C. Parlak, H.K. Maleh, J. Mol. Liq., 208, 122-129, (2015)

128. A.L. Linsebigler, G. Lu, J.T. Yates, Chem Rev. 95, 735-758, (1995)

129. B. Liu, L.L. McConnell, A. Torrents, Chemosphere. 44, 1315-1323, (2001)

130. C.E. Furlong, J.R. Richter, S.L. Seidel, L.G. Costa, A.G. Motulsky, Anal Biochem. 180, 242-247, (1989)

131. Y. Samet, L. Agengui, R. Abdelhedi, J. Electroanal. Chem. 650, 152-158,

132. Y. Samet, L. Agengui, R. Abdelhedi, Chem. Eng. J. 161, 167-172, (2010)

133. Y. Zhang, Y. Hou, F. Chen, Z. Xiao, J. Zhang, X. Hu, Chemosphere. 82, 1109-1115, (2011)

134. S. Agarwal, I. Tyagi, V.K. Gupta, M.H. Dehghani, A. Bagheri, K. Yetilmezsoy, A. Amrane, B. Heibati, S.R. Couto, J. Mol. Liq. 221, 1237 1242, (2016)

135. A.H. Soto, H.C. Gonzalez, M.M. Mora, J.S.C. Pampillo, C.E. Rodriguez, J. Hazard. Mater. 321, 1-8, (2017)

136. D.J. Karen, B.M. Joab, J.M. Wallin, K.A. Johnson, Chemosphere. 37, 1579 1586, (1998)

137. P. Pugliese, J.C. Molto, P. Damiani, R. Marın, L. Cossignani, J. Manes, J. Chromatogr. A. 1050, 185-191, (2004)

138. M.S. Hossain, A.N.M. Fakhruddin, M.A.Z. Chowdhury, M.K. Alam, J. Environ. Chem. Eng. 1, 270-274, (2013)

139. R. Zabar, M. Sarakha, A.T. Lebedev, O.V. Polyakova, P. Trebse Chemosphere. 144, 615-620, (2016)

140. K. Sivagami, B. Vikraman, R.R. Krishna, T. Swaminathan, Ecotox. Environ. Safe. 134, 327-331, (2016)

141. P. Salm, P.J. Taylor, D. Roberts, J.D. Silva, J. Chromatogr. B. 877, 568574, (2009)

142. L.R. Suntio, W.Y. Shiu, D. Mackay, J.N. Seiber, D. Glotfelty, Rev. Environ. Contam. T. 103, 1-59, (1988)

143. S. Chen, M. Chen, Z. Wang, W. Qiu, J. Wang, Y. Shen, Y. Wang, S. Ge, Environ. Toxicol. Pharmacol. 45, 179-186, (2016)

144. M.F. Rahman, M. Mahboob, K. Danadevi, B.S. Banu, P. Grover, Mutat. Res-Gen. Tox. En. Mutagen. 516, 139-147, (2002)

145. S.W. Hameed, M.A. Tahir, S. Kiran, S. Ajmal, A. Munawar, J. biosens. Bioelectron. 7, 1-4, (2016).

146. P. Wang, M. Rashid, J. Liu, M. Hu, G. Zhong, Food Chem. 212, 420-426, (2016)

147. M. Liu, Y. Hashi, Y. Song, J. Lin, J. Chromatogr. A. 1097, 183-187, (2005)

148. D. Wang, D.P. Weston, M.J. Lydy, Talanta. 78, 1345-1351, (2009)

149. A. Verma, Poonam, D. Dixit, Int. J. Environ. Sci. 3, 743-755, (2012) 